\title{
Je li Dioklecijanova palača ikad uistinu služila kao carska rezidencija?
}

\begin{abstract}
Dioklecijanova se palača u antičkim literarnim izvorima rijetko spominje, no po tome nimalo ne odudara od drugih carskih rezidencija. Opisi njezine veličine, oblika ili arhitektonskog izgleda, koji u kasnoj antici potpuno izostaju, stidljivo se javljaju tek u djelima kasnijih srednjovjekovnih pisaca, poput Konstantina VII. Porfirogeneta i Tome Arhiđakona, ali funkcija Palače tada se u potpunosti izmijenila. Upravo zahvaljujući djelima Konstantina VII. i Tome Arhiđakona, u osnovnim je crtama dobro poznata sudbina građevine od 7 . stoljeća nadalje, no zasada nedostaje temeljit odgovor na pitanje što se s njom događalo u posljednjim stoljećima zapadnorimske carske vlasti. Spoznaje temeljene na rezultatima novijih istraživanja upućuju na nužnost reinterpretacije dijela dosadašnjih tumačenja Dioklecijanove palače. U radu se naglasak stavlja na pitanje kakva je doista bila njezina namjena od trenutka izgradnje do propasti carske vlasti u zapadnome dijelu Carstva i je li ona ikada uistinu i imala funkciju prave carske rezidencije.
\end{abstract}

O Dioklecijanu, koji nedvojbeno pripada najznačajnijim vladarima na rimskome carskom prijestolju, manje kao o osobi, a više kao o vladaru, u hrvatskoj se historiografiji mnogo pisalo, poglavito zahvaljujući velebnom zdanju koje je odlučio podignuti u blizini Salone ${ }^{1}$, no zasad nedostaje opsežnija monografska obrada. Povijesne okolnosti nisu išle na ruku velikome caru reformatoru, pa je njegova osoba još uvijek u znatnoj mjeri obavijena velom tajni. Posljedica je to malobrojnih i izrazito šturih sačuvanih izvora kasne antike. ${ }^{2}$ Sudbina je, nažalost, htjela

BULIĆ 1919; BULIĆ I KARAMAN 1927; KARAMAN 1940a; Isti 1940b; NOVAK 2003; J. MARASOVIĆ I T. MARASOVIĆ 1968; DVORŽAK-SCHRUNK 1989; T. MARASOVIĆ 1995a; BELAMARIĆ 1998; Isti 1998²a; Isti 2003; CAMBI 1997; Isti 2003; MATULIĆ 2005; CAMBI 2005a; RAPANIĆ 2007; T. MARASOVIĆ I ALUJEVIĆ 2007; D. MARASOVIĆ 2009; CAMBI 2010; BUŽANČIĆ 2011; NIKŠIĆ 2012; MATIJAŠIĆ 2012: 43-62; CAMBI 2013. U spomenutim radovima navedena je i obimna domaća i strana literatura i o Dioklecijanu i o Palači.

2 Sve je izvatke iz literarnih izvora, koji se odnose neposredno na Dioklecijana, pedantno skupio i analizirao F. Bulić, u nastojanju da argumentira i dokaže tezu o zaleđu Salone kao mjestu Dioklecijanova rođenja. Usp. BULIĆ 1919. Rad pod duljim naslovom Car Dijoklecijan, njegovo ime, njegova domovina i mjesto, gdje se rodio; kada, gdje i kako je umro, izdan još daleke 1919 ., ponovno je objavljen 2005. u knjižici Dioklecijan i Split. U katalogu-monografiji SALONA 
da upravo Dioklecijanovo doba i zbivanja neposredno nakon njegove abdikacije ostanu dijelom zamračena jer pouzdani literarni izvori, poput ponajprije Res gestae Amijana Marcelina i, u nešto manjoj mjeri pouzdane, carske biografije u zbirci Historia Augusta, nisu sačuvani baš u onim dijelovima koji bi detaljnije osvijetlili to razdoblje. Srećom, careva je duga vladavina ipak ostavila i više nego dovoljno povijesnih tragova za rekonstrukciju njegove političke i vojne djelatnosti. ${ }^{3}$

Svi se sačuvani izvori slažu u tome da je bio podrijetlom iz Dalmacije te da je život skončao u svojoj vili, ali se značajno razilaze u navođenju uzroka smrti. ${ }^{4}$ Uloga posljednjega velikog progonitelja kršćana neposredno prije ključnog preokreta u odnosu carske vlasti prema kršćanstvu nedvojbeno je jedan od presudnih razloga ${ }^{5}$ zbog kojeg nam nije očuvan nijedan vjeran carev portret-skulptura, kojih je, s obzirom na njegovu dugu vladavinu, diljem Carstva moralo biti mnogo, pa ne znamo čak ni kako je Dioklecijan izgledao. ${ }^{6}$

Zanimljivo je da gotovo ista pitanja, na koja nema preciznih odgovora, možemo postaviti i uz carevu palaču. Ne zna se pouzdano ni kada je otpočela gradnja ${ }^{7}$, ni kada su građevinski radovi doista bili dovršeni. Većina se istraživača slaže da je gradnja morala otpočeti nakon uspostave tetrarhijskoga sustava 293. Ukoliko je

CHRISTIANA 1994: 109-195, izdanome povodom održavanja XIII. međunarodnoga kongresa za starokršćansku arheologiju, M. Ivanišević uvrstio je sve do sada u znanosti poznate literarne izvore koji se odnose na razdoblje od Dioklecijanovih progona do početka 7. stoljeća za prostor Dalmacije, a poglavito za Salonu i Split. Izvore koji se odnose na Dioklecijana i Salonu do prvog edikta protiv kršćana Ivanišević je podastro u trećem tomu ,triptiha“ o Saloni - LONGAE SALONAE 2002: 23-86.

3 Znanstvena je literatura o Dioklecijanu i tetrarhiji narasla do nepreglednosti. Novijeg su datuma i opsežnije KUHOFF 2001; DIOKLETIAN UND DIE TETRARCHIE 2004; DIOKLECIJAN, TETRARHIJA I DIOKLECIJANOVA PALAČA 2009. Usp. također WILLIAMS 1997; REES 2004.

4 Lact., DMP: 42, 3, navodi kako je umro od gladi i žalosti, slično kao i Euzebije iz Cezareje, dok je, pak, po Eutropiju (IX, 28) umro od starosti. Isto piše i Zosim (Hist.: 71). Nepoznati autor (Epitomae de Caesaribus: 39,7 ) tvrdi da se Dioklecijan otrovao u 68. godini života. Usp. BULIĆ 2005: 59-61.

5 Nije to, dakako, jedini razlog, niti je Dioklecijan bio posljednji progonitelj kršćana. Tu je politiku nakon razlaza s Konstantinom u istočnom dijelu države nakratko oživio Licinije. Carevi su portreti stradali i prilikom uništavanja skulptura njegova suvladara Maksimijana, kojega je Konstantin osudio na damnatio memoriae, što je značilo i uništenje Dioklecijanova lika i skulptura (zacijelo i onih unutar Palače), budući da su se kao suvladari prikazivali zajedno.

6 Glava iz istanbulskog arheloškog muzeja, atribuirana Dioklecijanu, mogla bi predstavljati i Aurelijana, baš kao i ona iz Arheološkog muzeja u Bursi, čija atribucija također nije pouzdana. Sačuvan je tek jedan kasnoantički literarni opis Dioklecijana, doduše iz kasnijeg vremena, kod Ivana Malale: „Bijaše ovaj visok, nježan, mršava lica, sijede kose i bijele brade, blijede puti, plavo-sivih očiju, debela nosa, veoma dobroćudan i silno naklonjen građenju." Prijevod preuzet iz RAPANIĆ 2007: 44 i bilj. 73.

7 CAMBI 2005a: 163; BELAMARIĆ 1999: 79, zastupao je mišljenje kako je gradnja otpočela tek nakon okončanja Dioklecijanova pokoravanja Egipta 298. 
doista tako, sâmi radovi zacijelo nisu mogli početi prije 294., a vrlo vjerojatno i kasnije, uzme li se u obzir vrijeme potrebno za izradu sâmoga projekta i osiguranje radne snage te izvršenja brojnih ostalih pripremnih radnji. ${ }^{8}$ Prevladavajuće je mišljenje kako je palača uglavnom dovršena s carevom abdikacijom, a da su se daljnji radovi vjerojatno nastavili kraće, pobliže neodređeno, vrijeme nakon Dioklecijanova dolaska u Palaču. Nije nam poznato ime arhitekta ili arhitekata, kao ni prava izvorna namjena građevine ${ }^{9}$, a ne možemo potvrditi ni je li Dioklecijan doista bio i njezin idejni kreator. Ne možemo, na kraju, s potpunom sigurnošću kazati ni kome su bili posvećeni hramovi u palači. ${ }^{10}$ Ono što nam je o Palači najbolje poznato jest praktički ono što danas možemo vidjeti ili djelom rekonstruirati - supstrukcije, perimetar zidina, dimenzije i raster uz, dakako, Peristil, mauzolej i Mali hram. Zahvaljujući tome što supstrukcije palače jasno pokazuju kako je izgledao gornji kat ${ }^{11}$, najbolje nam je poznat izgled južnoga

CAMBI 2010: 171; Isti 2014: 127: „Zidanje arhitektonskog kompleksa moralo je otpočeti s južne, morske strane. Pristanište je bilo prvo na redu, a potom je slijedila izgradnja supstrukcija te konačno ostali dijelovi palače. Materijal je iz luke dovođen rampama i stubama bez kojih premoštavanje visinskih razlika nije bilo moguće“. S tom se tvrdnjom uistinu teško složiti. Gradnja je u svakom slučaju morala otpočeti izmjerom terena, poslom što su ga i u Dioklecijanovo doba obavljali rimski agrimensori, a druga je faza morala biti raščišćavanje terena, označavanje trasa i kopanje temelja, bez obzira na to jesu li se oni polagali na čvrstu stijenu ili u iskop. Taj posao nije kolidirao s istodobnom izgradnjom pristaništa, bez kojeg uistinu nije moglo biti govora o gradnji. No, tvrdnja kako je zidanje otpočelo s južne strane izgradnjom supstrukcija te konačno potom ostalih dijelova palače nije prihvatljiva. Palača je složen arhitektonski kompleks i ne sastoji se od jednog jedinstvenog arhitektonskog dijela, već od cijelog niza raznolikih i graditeljski različito zahtjevnih objekata. Svaki je od objekata (hramovi, mauzolej, supstrukcije, zidine, vrata, kule) morao imati vlastitu logiku i slijed, pa i materijal i brzinu gradnje. Dijelovi građevina, ponajprije brojni monolitni stupovi, kapiteli i arhitektonski ukrasi, izrađivali su se ili pljačkali drugdje te se dopremali na gradilište, da bi se potom, u različitim fazama gradnje, ugrađivali. Logika gradnje uvjetovala je da se iz pristaništa građevni materijal distribuira na različite lokacije unutar gradilišta, u većoj količini skladišti na mjestima lako dostupnima za pojedine gradnje $i$, shodno tome, nalagala je stalno slobodne i lako pristupne staze za dostavu kamena. Da su najprije sagrađene supstrukcije, dostava bračkog kamena, kao građevnog materijala, bila bi moguća jedino kroz malena južna morska vrata. Sasvim je očito da su se najprije ugrubo morali sagraditi svi unutarnji objekti, pa su zidari prvi dovršavali posao. Prve dovršene građevine morale su, shodno tome, biti mauzolej, hramovi i prostor Peristila, a tek potom supstrukcije palače, što, naravno, ne isključuje njihovo temeljenje i najgrublje zidarske radove.

9 Usp. DVORŽAK-SCHRUNK I BEGOVIĆ 2012: 507-508. Uvriježenim tumačenjima Dioklecijanove palače, kao kombinacije utvrđenog vojnog logora i ladanjske vile, sagrađene u pitomoj, gotovo nenastanjenoj uvali, protive se arheološka otkrića posljednjih godina, kao i nove spoznaje, do kojih se došlo radovima na sanaciji Palače. Od čitavog građevinskog sklopa tek je njegova južna četvrtina služila kao rezidencijalni dio.

10 MARASOVIĆ 1995b: 89-103, donosi cjelovit kronološki pregled vrela i mišljenja autora o atribuciji hramova u Palači. Usp. CAMBI 2003: 107-108.

11 MARASOVIĆ 1994: 74-75; MARASOVIĆ I ALUJEVIĆ 2007: 156 i d.; DEMICHELI 2009: 56; BUŽANČIĆ 2011: 15. 
dijela građevine, u kojem se nalazio Dioklecijanov stan. Sjeverni dio palače, nažalost, mnogo je slabije očuvan i istražen. No, budući da su sve to pitanja o kojima se uvelike raspravljalo u starijim, kao i u brojnim recentnim radovima domaćih i stranih autora ${ }^{12}$, njima se u ovome prilogu ne namjeravam detaljnije baviti, osim ukoliko bi se to gdjegdje doista pokazalo neizbježnim. Od domaćih se stručnjaka najčešće u raznim prilikama Dioklecijanu, Palači i njezinu skulpturalnom programu vraćao N. Cambi.

Hrvatska je znanost još od prvih znanstvenih radova o Palači razvila tezu kako je to zdanje predstavljalo dobro utvrđenu carsku rezidenciju vladara, koji je, doduše, abdicirao s prijestolja, ali je i dalje na neki način participirao u obnašanju vlasti. Takvo je viđenje predstavljalo temeljno polazište u daljnjem razvijanju ideje, koja je nužno vodila do danas prevladavajućega gledišta kako je Palača kao takva trebala poslužiti kao trajni spomenik tetrarhiji i njezinu utemeljitelju, Jupiterovu sinu. ${ }^{13}$ Postavka je, dakle, bila ovdje i samo ju je trebalo dodatno potkrijepiti argumentima. Budući da onih čvrstih, nažalost, nije bilo, spas je pronađen u domišljanjima s područja simbolike i ikonografije. Na opće prihvaćanje naišla je teza, koju je šezdesetih godina prošlog stoljeća iznio H. Kähler. ${ }^{14}$ On je pretpostavio da su se na pet postamenata iznad pročelja sjevernih vrata nalazili kipovi tetrarha s Jupiterovim kipom na središnjem, najvišem postolju, a ti su kipovi pripadali tetrarhijskoj propagandi. No, to uistinu ne može biti ništa više doli pretpostavka nepotkrijepljena dokazima. ${ }^{15}$ Nikakve skulpture, naime, nikad nisu pronađene u blizini sjevernih vrata, kao ni njihovi ostaci, a kako pokazuju najnovija istraživanja, uključivši i sondiranje zida od opeke ponad Zlatnih vrata, one nisu nikad ni bile postavljene na postamente na vrhu zida. Do danas su sačuvana četiri postamenta, ali na Adamovim slikama vidljivo ih je pet ${ }^{16}$, kao i na Niemannovoj rekonstrukciji iz 1910. Baze se danas uglavnom ne nalaze na izvornim pozicijama, a i njihov prvotan broj nije pouzdan, pa ih je, primjerice, moglo biti i šest. Jednako tako, pokazalo se da su i niše na nižim razinama pročelja, predviđene za dekoraciju, ostale prazne. ${ }^{17}$ Simbolika slavljenja tetrarhije željela

12 Literatura o Palači doista je opsežna, a temeljito je navedena u RAPANIĆ 2007. Najnoviji pregled literature o Dioklecijanu u CAMBI 2010. Pregled novijih istraživanja i radova na sanaciji: MARINKOVIĆ 2010.

13 CAMBI 2002; MARASOVIĆ 2009: 13.

14 KÄHLER 1965: 106 i d.; MARASOVIĆ 1994: 58-59; CAMBI 2002: 173-175. Iako se radi tek o pretpostavci bez ikakve potvrde, ona se često uzima kao neupitna činjenica na kojoj se grade daljnja razmišljanja. Usp. CAMBI 2002: 141; Isti 2002a; Isti 2005a.

15 Usp. MARINKOVIĆ 2014: 292-293 i bilj. 4 i 5.

16 ADAM 1764: tab. XII. Adam je, međutim, sve baze nacrtao jednake veličine, što one nikako nisu; VLAŠIĆ JURIĆ 2011: 208-210.

17 Usp. NIKŠIĆ 2012: 232-233. 
se iščitavati i iz broja hramova u Palači, kojih je, koliko je poznato, bilo četiri. ${ }^{18}$ U cijeloj priči brojne nelogičnosti nisu se uzimale u obzir, dok su se tek pretpostavke prihvaćale kao gotove činjenice, na temelju kojih se nastavljalo graditi daljnja razmišljanja. Pritom su se često zanemarivali podaci vremenski najbližih literarnih izvora, a katkad, osobito u ranijoj fazi, i neki od rezultata arheoloških istraživanja Palače i njezine neposredne okolice. ${ }^{19}$ Tijekom radova na uređenju rive otkrivena je rimska obala i pokazalo se da južni zid Palače nije bio građen na samoj morskoj obali, kako se desetljećima vjerovalo. Ondje su se nalazila lučka postrojenja, čime je cijeli južni zid s kriptoportikom ustvari bio neutvrđen i nebranjen. I ostale su nelogičnosti fortifikacijskoga sustava ostale neobjašnjene. Palača je svojim položajem, nižim od okolnog zemljišta, potpuno nepodesna za obranu, a zidine sa svih triju kopnenih strana imaju preširoke i prenisko postavljene lučne otvore. Veliki se lučni otvori nalaze i iznad svih kopnenih vrata, a vrata su uvijek najslabija točka obrane. Carski je stan, pak, u odnosu na ostatak sklopa, prilično skučenih dimenzija. Rezidencijalni dio tako zauzima tek četvrtinu prostora unutar zidina $^{20}$, a usto, osim kriptoportika, čija je namjena bila tek komunikacija između prostorija stana, ni one, osim vrata, nemaju nikakve druge komunikacije prema okolnom ambijentu. Taj je prostor s visoko postavljenim prozorima i svjetlarnicima arhitektonski zatvoren i prema unutarnjem dijelu građevine. Brojne nelogičnosti u gradnji nastojalo se objasniti brzinom radova, nedovršenošću ili pogreškama projektanata, koje su graditelji rješavali u hodu. ${ }^{21}$ No, novija postignuća na tom polju i spoznaje stečene tijekom intenzivnih radova na sanaciji Palače upućuju na potrebu temeljite reinterpretacije izvorne namjene građevine. Većina znanstvenih autoriteta i dalje pristaje uz tezu kako je car i nakon abdikacije zadržao određene prerogative vlasti i kako je Palača trebala poslužiti kao „... spomenik najprije živom, a poslije mrtvom caru što je svojim djelom zadužio svakog Rimljanina." ${ }^{\text {22 }}$ Najsažetije i najjednostavnije to je mišljenje izložio N. Cambi: „Nastanak, arhitektonski oblik i dekoraciju Dioklecijanove palače valja nam promatrati u svjetlu povijesnih zbivanja, u skladu s Dioklecijanovom politikom i vladanjem. Palača je odraz ideja koje su vodile njegova (sic!) tvorca, vladara koji je držao da je osigurao

18 Toma Arhiđakon u Palači navodi tri hrama posvećena Jupiteru, Asklepiju i Martu. Jedan je od njih u cijelosti sačuvan (srednjovjekovna krstionica), dok su od drugih dvaju sačuvani samo ostaci temelja kružnoga tlorisa. Mnogo kasniji podatak, da su bili posvećeni Janu, Kibeli i Veneri, još je diskutabilan. Usp. CAMBI 2003: 108; WILKES 1993: 55-56; BABIĆ 2004: 719 i d.; JELIČIĆ-RADONIĆ, 2011: 18-23; MARASOVIĆ 2011: 689-695; MATIJAŠIĆ 2012: 36, jedini uz tri hrama zapadno od Peristila smješta još jedan, četvrti hram, posvećen Asklepiju.

BELAMARIĆ 2004: 28.

20

BASIĆ 2010: 68.

21 Usp. NIKŠIĆ 2012.

22 CAMBI 1997: 42; Isti 2005a: 164. 
čvrst temelj poljuljanom carstvu. Ona je, prema tome, rezidencija reformatora i spasitelja, ali i spomenik najprije živom, a poslije mrtvom caru što je svojim djelom zadužio svakog Rimljanina. Arhitektura je morala sadržavati oblike koji će pružiti visok stambeni standard, osigurati ceremonijal koji je vjerojatno bio sličan onome na nikomedijskom dvoru, pružiti sigurnost od potencijalnih uzurpatora vlasti ili carevih neprijatelja, održavati simboliku svih reforma i pružiti dostojni grob i spomenik nakon vladareve smrti. Ove su potrebe logične pa i kad se ne bi čitale iz arhitekture i dekoracije, bilo bi ih moguće pretpostaviti. “23 Objektivno govoreći, teško da su suvremenici mogli imati takav stav o Dioklecijanu. Njegov kruti fiskalizam, vezivanje kolona za zemlju, kao i svih stanovnika za njihova zanimanja, porast cijena, inflacija i stroge kazne (izrijekom navedene u Ediktu o cijenama) te progoni kršćana sigurno nisu bili razlozi zbog kojih bi car i njegovi suvladari bili omiljeni u širim društvenim slojevima, a ni među aristokracijom. Prije je riječ o stereotipu i vrlo pojednostavnjenome gledanju na carevu ličnost, koje teško da može imati ikakve veze s okrutnom stvarnošću. Moramo imati u vidu činjenicu da mi danas iščitavamo tu gradnju temeljeći svoja razmišljanja i stavove isključivo na osnovi osobnog doživljaja, kako vidljivih ili onih oku skrivenih arhitektonskih ostataka, tako i na vlastitoj prosudbi karaktera ličnosti iz davno prošlog vremena, osobe o kojoj u biti ne znamo gotovo ništa. Slijed vlastite logike na taj nas način često može odvesti do nama samorazumljivih, a u stvarnosti možda i potpuno pogrešnih zaključaka. „No, istini se katkad, pa čak i u znanstvenim raspravama, ne voli pogledati u oči. Često smo svjedoci da se vrlo rado ustraje na nekome mitu, nečemu sasvim nerealnome, čak nedokučivome, ali uhu 'ugodnome'، “24

Nažalost, htjeli-ne htjeli, moramo na kraju priznati da su mnogi elementi priče o Dioklecijanu i njegovoj palači u znanstvenome smislu vrlo dvojbeni, a počivaju u znatnoj mjeri na krhkim temeljima imaginacije. ${ }^{25}$ Dakako, svi autori naglašavaju Dioklecijanove zrele godine prilikom abdikacije, ali u njihovim se daljnjim razmatranjima ta činjenica u pravilu gubi u neobjašnjivoj idealizaciji careve osobe,

23 Isti 1997: 41-42; Isti 2005a: 163-164.

24 RAPANIĆ 2007: 102. Lijepo je to obrazložio I. Bošković: „Priča o Palači (od koje će nastati grad) i njezinu graditelju, koji će u njoj u nerazjašnjenim okolnostima skončati, s vremenom će - po zakonima (pučke) imaginacije, brojnih prefiguracija i konfabulacija - dosegnuti do mita, koji će se - naslagama najrazličitijih dotoka - održati do danas i biti sastavnim dijelom žive i neuništive memorije (pamćenja) grada, njegova kolektivnog identiteta i mentaliteta.“ BOŠKOVIĆ 2008: 403.

25 RENDIĆ MIOĆEVIĆ 1992: 99-115, iznio je pretpostavku, dakako prihvaćenu, da se na mjestu središnjeg petog interkolumnija unutarnjeg friza Dioklecijanova mauzoleja, uništenog probijanjem prozora u 17. stoljeću, nalazio prikaz orlova lika, Jupiterova simbola. Za to, osim iščitavanja simbolike friza, nema nikakvih potvrda. CAMBI 1997: 73 (Isti 2005a: 179) ide i korak dalje, pa na leđima orla pretpostavlja i manje biste Dioklecijana i Priske. 
koji kao da najednom postaje izvanvremenski lik, a njegova Palača „,.. spomenik najprije živom, a poslije mrtvom caru...".26

Od brojnih istraživača koji su se bavili Dioklecijanovom palačom ili njezinim utemeljiteljem, vrlo se mali broj njih tek dotaknuo pitanja vezanih uz sudbinu palače u stoljećima koja su slijedila neposredno nakon smrti njezina tvorca. ${ }^{27} \mathrm{Go}-$ tovo svi autori zadovoljavali su se konstatacijom koju je iznio još F. Bulić, kako je, naime, palača nakon Dioklecijanove smrti ostala carski posjed i tek povremeno usputno boravište pojedinih članova carske obitelji. ${ }^{28}$ Stoga je potpuno opravdano aktualizirati pitanje koja je bila izvorna namjena Palače i je li ona ikada uistinu i služila kao carska rezidencija ili je bila tek jedan od brojnih carskih posjeda kakvih je bilo diljem Rimskoga Carstva. Nije naodmet prije toga pokušati još jednom podvući jasnu terminološku distinkciju, naizgled i samorazumljivu, između pojmova carska rezidencija i carska vila. ${ }^{29}$ Promatramo li carsku rezidenciju (palatium) službenim boravištem stalnog ili, u najmanju ruku, trajnijeg karaktera, onda će to istodobno biti i sjedištem većeg ili manjeg broja visokorangiranih dužnosnika carske administracije te brojnih drugih pratećih sadržaja nužnih za funkcioniranje dvora, uprave i državnog aparata. ${ }^{30} \mathrm{U}$ tetrarhijsko doba, s obzirom na prirodu i specifičnosti tog oblika vladavine, u neposrednoj blizini dvora nalazili su se i cirk, kovnica novca te tvornica oružja (fabrica scutaria et armorum), a eventualni izostanak ponekog od tih sadržaja predstavlja doista tek iznimku koja potvrđuje pravilo. ${ }^{31}$ To bi, dakako, ukoliko je car poživio dovoljno dugo, kao što je to Dioklecijanov slučaj, trebao biti i dom careve obitelji ${ }^{32}$, kao i svih onih osoba koje su iz raznih razloga bile neposredno vezane uz cara. Nasuprot tome, carske bi vile, kakve su posjedovali svi rimski carevi, bile ponajprije mjesta ladanjskog boravka (villa) i privremenog, često tek usputnog, boravišta vladara. Možda je najbolji primjer za to čuvena Hadrijanova vila u Tiburu (dan. Tivoli), o kojoj se nakon smrti njezina stvaratelja također u literarnim izvorima ne nalazi spomena.

$26 \quad$ CAMBI 1997: 42; Isti 2005a: 164.

27 DVORŽAK-SCHRUNK 1989; RAPANIĆ 2007; DVORŽAK-SCHRUNK I BEGOVIĆ 2012. Samo o Dioklecijanovu boravku u Palači nakon abdikacije CAMBI 2010: 169-194. i ondje nav. lit.

BULIĆ I KARAMAN 1927: 180; DYGGVE 1996: 24; BELAMARIĆ 1998²: 30.

KUHOFF 2001: 746. O tome opširnije RAPANIĆ 2007: 90 i d. O tom se pitanju češće raspravljalo. Usp. BULIĆ I KARAMAN 1927; BASIĆ 2010.

KUHOFF 2001: 731. O podrijetlu imena palatium usp. Cass. Dio., LIII 16, 5-6.

31 O tome opširnije KUHOFF 2001: 716 i d., 731.

32 Ako je vjerovati Laktancijevu navodu (DMP: 15, 1), prilikom progona kršćana Dioklecijan je prije svih prisilio svoju kćer Valeriju i ženu Prisku da žrtvuju bogovima. Obitelj je, dakle, uz cara u palači u Nikomediji. Podatak je ipak ponešto dvojben jer je Valerija tada već Galerijeva supruga, pa je pomalo čudno da bi joj to zapovjedio Dioklecijan, a ne Galerije. No, prema rimskim običajima, Dioklecijan je bio pater familias, a ne Galerije. 
No, često između tih dvaju termina nije baš jednostavno povući jasnu granicu. Nije li, primjerice, Tiberijeva vila na Capriju bila mjesto višegodišnjeg careva prebivališta? Bismo li je pritom nedvojbeno mogli okarakterizirati i službenom carskom rezidencijom, znajući da se stvarna vlast nalazila u rukama prefekta pretorija Sejana, a formalno političko središte države u Rimu? Bismo li, nadalje, Maksencijevu vilu na Siciliji, kraj Piazze Armerina (Villa del Cassale), bili skloni smatrati službenom carskom rezidencijom, ako je ta vila uopće bila carski posjed, a ne vlasništvo namjesnika Sicilije Lucija Valerija Aradija Prokula?

Carskih je službenih rezidencija u tetrarhijsko doba, pri čemu ovdje mislim na prvu tetrarhiju, kao što je poznato, bilo više od četiriju. Glavna Dioklecijanova rezidencija bila je u Nikomediji (dan. Izmit), a njegov suvladar Maksimijan stolovao je najprije u Lugdunu i u Trieru (Augusta Treverorum), a tek nakon utemeljenja tetrarhije u Mediolanu. No, prva je Dioklecijanova rezidencija bila u Sirmiju, koliko zbog toga što je vanjskopolitička situacija zahtijevala carevu aktivnu ulogu na dunavskoj granici, toliko i stoga što u vrijeme njegova preuzimanja vlasti nikomedijska carska palača nije ni postojala. ${ }^{33} \mathrm{U}$ Sirmiju je Dioklecijan pouzdano boravio 290. i 291. te 293. i 294., a vrlo je vjerojatno u tom gradu na Savi boravio i od 287. do 289. ${ }^{34}$ Vojna je potreba uvjetovala i to da je Dioklecijan povremeno rezidirao i u Antiohiji, a ako je vjerovati Laktanciju, jedno vrijeme i u Egiptu. U Antiohiji Dioklecijanova je nazočnost potvrđena za 287., 290., 297. -298. i 299. -301., dok se o eventualnoj egipatskoj rezidenciji ne zna ništa.

Službena je pak rezidencija Dioklecijanova cezara Galerija od 298. bila u Tesaloniki ${ }^{35}$, dok je cezar augusta Maksimijana Konstancije svoju carsku rezidenciju

33 Lact., DMP: 7, 8-10; BUŽANČIĆ 2011: 7. U Nikomediji, metropoli provincije Bitinije, izgradnja carske palače i pratećih sadržaja nije mogla otpočeti prije 287. ili 288., pa čak i još kasnije jer je Dioklecijan najprije morao osigurati, a zatim i učvrstiti vlast. Teško da je u tim trenucima imao vremena razmišljati o odabiru rezidencije, a kamoli o njezinu izgledu. Potkraj svibnja 285. na rijeci Margu (Velika Morava), negdje između današnjeg Smedereva i Kostolca, porazio je Karina (SHA: XXX, XVIII, 2), a zatim se upleo u sukobe s Kvadima i Markomanima, da bi tek potom mogao proslijediti prema Italiji. U srpnju 285. u Mediolanu imenovao je cezarom Maksimijana, a nakon toga sporo je krenuo prema istoku, zadržavši se u Podunavlju kako bi tijekom studenoga porazio Sarmate. Unatoč uspjehu, nije uspio osigurati konačnu i odlučnu pobjedu. Prezimio je u Nikomediji, gdje je njegova nazočnost posvjedočena jednim reskriptom, koji datira od 3. ožujka 286. O tim ranim zbivanjima usp. BARNES 1982: 50, 113; Isti 19965: 5-6; POTTER 2005: 280-281, 649; WILLIAMS 1997: 37-38, 41-43, 45, 52. Vjerojatno je tek tada imao prilike i vremena razmišljati o novoj prijestolnici i gradnji nove palače. Kako zaključuje Kuhoff, gradnja je zapravo bila normalna posljedica podjele vlasti na dvije, kasnije četiri osobe, budući da je bilo potrebno smjestiti comitatus u rezidencije u različitim dijelovima Carstva. Logično je da je Sirmij bio prva glavna Dioklecijanova prijestolnica (ondje je prezimio 289./290. i 290./291.), sve do uvođenja tetrarhije, kad je provedena nova podjela oblasti. KUHOFF 2001: 717-718. Do tada je vjerojatno nova nikomedijska palača uglavnom bila dovršena (njegove decennalia proslavljene su u Nikomediji). Nažalost, njezini su arheološki ostaci i više nego skromni.

34 KUHOFF 2001: 717. Posljednji spomen Dioklecijanova boravka u Sirmiju vremenski pada u prvu polovinu 304., tijekom povratka iz Rima u Nikomediju.

35 KUHOFF 2001: 717, 726-727. 
imao u Trieru (Augusta Treverorum) ${ }^{36}$ Nema dvojbe da je premještanje carskog sjedišta na dulje ili kraće vrijeme moralo biti uvjetovano vojnim, političkim ili nekim drugim valjanim razlozima. Za vrijeme ratnih operacija na istoku Galerijeva je rezidencija vjerojatno bila Antiohija. Upravo je carska rezidencija u Antiohiji postala službenim sjedištem i kasnijeg tetrarha, cezara Maksimina Daje. I on je potom sebi dao graditi palaču za umirovljenje, nikad dovršenu, u današnjem Šarkamenu u istočnoj Srbiji. ${ }^{37}$ Nakon što je postao august Galerije je prijestolnicu preselio u Serdiku. ${ }^{38}$ Potpuno je razumljivo da je sjedište vlasti zahtijevalo postojanje stambenog dijela za cara i članove njegove obitelji, blagovaonice, terme, sobe za prijem i sobe za sjednice vladara i vojnog vijeća, aule predviđene za veća okupljanja, prostorije za službenike središnje vlasti i zgrade namijenjene posluzi i vojnoj zaštiti, kao i skladišne prostorije. ${ }^{39}$

Očito je namjera trojice tetrarha (Dioklecijan, Galerije, Maksimin), za koje je potvrđeno da su dali graditi palače, bila osiguravanje boravišta nakon predviđenog odstupanja s carske vlasti. Galerijeva se novosagrađena palača za umirovljenje nalazila u Romulijani (dan. Gamzigrad u Srbiji), dok se Maksimijanovo boravište nalazilo na danas nepoznatome mjestu negdje u Lukaniji u južnoj Italiji ${ }^{40}$, a prema Laktanciju možda u Kampaniji ${ }^{41}$ Ne postoji sačuvan trag u izvorima da je Maksimijan za svoje stare dane dao graditi neku novu vilu. No, budući da je za boravište odabrao Italiju, gdje je carskih posjeda bilo mnogo, to vjerojatno i nije bilo nužno. Za svoje je boravište mogao odbrati i neku od već postojećih. Ni za Maksimijanova cezara Konstancija literarni izvori ne spominju je li igdje sagradio ili uopće namjeravao graditi palaču za predviđene godine umirovljenja. Iako je tetrarhijski sustav promišljeno predviđao abdikaciju augustâ u nekom trenutku i njihovu smjenu cezarima, sâm trenutak abdikacije zasigurno nije bio unaprijed dogovorno određen. ${ }^{42}$ Uvjeren sam da se to nikad i nije predvidjelo jer je uvijek

\footnotetext{
Isto: $723-724$.

37 TOMOVIĆ 2005; Isti 2009; CAMBI 2010: 170.

38 KUHOFF 2001: 716, 730-731.

39 Isto: 731.

40 Eutrop., Breviarium: IX, 28; X, 2. Vila na Siciliji kraj Piazze Armerina gdjegdje se navodi kao Maksimijanova gradnja za umirovljeničke dane, ali o tome u literarnim izvorima nema nikakve potvrde. Maksimijanovim se boravištem izričito navodi ili Kampanija ili Lukanija.

41 Lact., DMP: 26, 7.

42 Drukčije CAMBI 2010: 170: „Reformska nakana bila je da augusti napuste tron nakon približno dvadeset godina vladavine, a da položaj i naslov prepuste cezarima, koji će na svoje mjesto uzeti nove cezare. Reforma je trebala osigurati kontinuitet jer se smjena obavljala sredinom razdoblja (nakon deset godina cezarskog položaja slijedilo bi deset augustovskih godina." No, takve interpretacije ne potvrđuje nijedan sačuvan literarni izvor, a ni poznata povijesna zbivanja. Zbog toga i Cambi dvoji. Usp. CAMBI 2010: 169 i bilj. 3, ali i njegovo mišljenje na drugome mjestu: „U trenutku kad je 1. ožujka godine 293. Dioklecijan na čast mlađeg suvladara uzdigao Galerija, a Maksimijan Konstancija, abdikacija je, kao logično i suvislo rješenje sustava, očito
} 
postojala mogućnost pogibije, umorstva ili iznenadne prijevremene smrti jednoga, pa i obojice augusta. U tome bi slučaju cezar automatski postajao novim augustom.

Već je odavna, od prvih novovjekovnih razmatranja o Dioklecijanovoj palači, preko njezinih prvih detaljnijih opisa i ranih istraživanja uočeno kako građevina ponajprije ima oblik i izgled utvrđenoga vojnog logora (castrum), čemu se možda i ne treba čuditi znamo li da je Dioklo prije stupanja na carsku čast bio profesionalni vojnik sa zavidnom karijerom. Ustvari Palača je, prema riječima M. Suića, prvi i najblistaviji primjer ostvarenja ideje palače-kastruma na pragu kasne antike s objedinjenim elementima antičkoga grada, vojnog logora i raskošne vile. ${ }^{43}$

O vlastitim pogledima na izgled i oblik careva boravišta, kao i pretpostavljenim razlozima za to pisali su svi znanstveni autoriteti koji su se detaljnije bavili Palačom, ali o mnogim pitanjima vezanima uz tu problematiku još uvijek nije postignut konsenzus. Tako jedinim sigurnim općim mjestom, potvrđenim i literarnim izvorima ${ }^{44}$, ostaje tek činjenica kako se car nakon abdikacije povukao u Palaču, u kojoj je nedvojbeno namjeravao proživjeti posljednje godine života. Je li ih želio provesti u miru ili je težio zadržati politički utjecaj i nastaviti ,iz sjene" upravljati državnim poslovima? Čini se da u tom pitanju leži ključ za odgovore na cijeli niz zagonetki, vezanih uz Dioklecijana i ulogu Palače u vrijeme neposredno prije careve abdikacije, poslije nje, a zatim i nakon njegove smrti. Dioklecijanova palača svakako jest bila rezidencija jednog uglednika i moćnika, ali teško je ne složiti se s konstatacijom kako za Dioklecijanova života ona nije mogla imati službeni, već isključivo privatan karakter. Ključno je, dakle, pitanje Dioklecijanova stvarnoga statusa nakon abdikacije.

već bila usustavljena. Možda je bio neizvjestan samo trenutak abdikacije. “CAMBI 2005: 163. Cezari Konstancije i Galerije, imenovani 293., na položaj augusta stupaju 305., što čini dvanaest godina obnašanja cezarske časti. Osim prve, nijedna tetrarhija nije potrajala tako dugo da bismo imali osnove i potvrde o jasno uspostavljenom i definiranom principu. Na kraju krajeva, i carska je abdikacija u Carstvu bila presedan, a o tetrarhijskim idejnim aspektima smjene vlasti donosimo zaključke tek na temelju poznatih povijesnih zbivanja. O usustavljivanju tetrarhije i pitanju abdikacije usp. KOLB 1987: 297 i d. i KUHOFF 2001: 128 i d.

43 SUIĆ 2003: 358.

44 U svim sačuvanim spomenima u kasnoantičkim literarnim izvorima to se zdanje beziznimno naziva villa. Hieron., Chron., s. a. 316. „Diocletianus haud procul a Salonis in villa sua Spalato moritur.“; Eutrop., Breviarium: IX, 28. „Diocletianus privatus in villa, quae haud procul a Salonis est, praeclaro otio senuit.“; Chron., Gall., a. 511, „IX anno Constantini Diocletianus obiit Ophinio in villae suae palatio apud Salonas." I u 6. stoljeću vilom je naziva Marcelin Komes, osvrćući se na ubojstvo Julija Nepota. Marcell. Com., Chron., s. a. 480: „His consulibus Nepos, quem dudum Orestes imperio abdicaverat, Viatoris et Ovidae comitum suorum insidiis haut longe a Salonis sua in villa occisus est". Termin Palača (palatium) prvi se put javlja u srednjovjekovnim tekstovima. Osim Konstantina VII. Porfirogeneta, tako je naziva Toma Arhiđakon, baveći se etimologijom imena (HS c. X), a zatim termin ulazi i u gradski Statut te komunalni pečat (1312.) (Palatium laetum Spalatum Salonae quietum), BASIĆ 2012: $10 \mathrm{i} \mathrm{bilj.}$ 1 i 2; RAPANIĆ 2007: 173; KUHOFF 2001: 746. 
Jedina gradnja intencionalno i kronološki bliska Dioklecijanovoj palači jest ona Galerijeva u Gamzigradu. Gradnja Galerijeve umirovljeničke palače često se dovodi u posljedičnu vezu s Dioklecijanovom gradnjom. ${ }^{45} \mathrm{Je}$ li Galerije bio potaknut Dioklecijanovim primjerom ili je, neovisno o njemu, razmišljao o povlačenju u rodni kraj, teško da ćemo ikad saznati. Obje gradnje, međutim, pokazuju mnogo više razlika negoli sličnosti. ${ }^{46}$ Dioklecijanova je palača po svome položaju villa maritima i villa suburbana ${ }^{47}$, dok je Galerijevo zdanje smješteno u tipično rustikalnu krajoliku, udaljeno od većih aglomeracija. Gradnje se, nadalje, drastično razlikuju po prostornoj i tlocrtnoj koncepciji, kao i po unutrašnjoj dispoziciji i artikulaciji. ${ }^{48}$ Nasuprot Dioklecijanovoj gradnji, pravokutnog tlorisa s pravilnim rasterom ulica, Romulijana pruža sliku složenog i razvedenog arhitektonskog sklopa, čijem planu nedostaje čvrstina. Ovdje nema izraženih komunikacija u pravcu sjever - jug, dok jedina dužinom izraženija komunikacija, ona u smjeru istok - zapad, kako se čini, nije bila kontinuirana i na više mjesta pokazuje lom. Također, između građevina i bedema koji ih okružuju ne nazire se ikakva organska veza, a svaka arhitektonska cjelina djeluje poput samostalne i slobodne prostorne organizacije, odajući dojam kako prvotan idejni plan ili nije postojao ili se od njega odustalo već na početku gradnje. ${ }^{49}$ Razlike ovdje ne prestaju jer su svakako obje te gradnje imale i funerarnu funkciju. Ključna je građevina Dioklecijanove palače mauzolej, koji je stoga i smješten u sâmome njezinom središtu, a uz cara mjesto je u njemu trebala naći i njegova supruga Priska. U gamzigradskoj palači dva su mauzoleja smještena izvan zidina, na obližnjem brežuljku. Prema uvjerljivim tumačenjima njihovih istraživača, jedan je pripadao Galeriju, a drugi njegovoj majci Romuli. Jedina su istinska sličnost tih dvaju arhitektonskih kompleksa, uz njihovu namjenu sigurnog boravišta umirovljenih vladara, fortifikacije, ali i ovdje postoje znatna odstupanja, ne samo u materijalu i tehnici gradnje. Gamzigradska su utvrđenja s bedemima debljine 3,65 metara mnogo robusnija i pouzdanija od onih Dioklecijanove palače, a njezin je smještaj povoljniji za obranu. Sve su kule Romulijane poligonalne s kružnom osnovom iznutra, a one koje su štitile glavni ulaz imaju zid debljine 3,70 metara. ${ }^{50}$ Dioklecijanovu palaču štitile su pak

\footnotetext{
45 KUHOFF 2001: 762; CAMBI 2005a: 165.

46 Drukčije KUHOFF 2001: 782. Prema njegovu mišljenju, obje gradnje pokazuju očite sličnosti, ali postoje i određene razlike.

47 SUIĆ 2003: 358-359; DVORŽAK-SCHRUNK I BEGOVIĆ 2012: 508-509. Drukčije KUHOFF 2001: 744. Njegov je zaključak kako Dioklecijanova, kao ni Galerijeva vila, nisu bile smještene u neposrednoj blizini grada, pa se nikako ne mogu klasificirati kao villae suburbanae. No, Salona je i dovoljno velik grad i dovoljno blizu Palače, a da bismo taj zaključak okarakterizirali kao neprihvatljiv.

KUHOFF 2001: 767.

GAMZIGRAD 1983: 53.

Isto: 36.
} 
kule pravokutnog i oktogonalnog tlocrta. Unatoč navedenim razlikama, teško je osporiti mišljenje da su obje te gradnje na simboličkoj razini kroz skulpturalni ukras trebale veličati vlastite tvorce. U tom pak smislu Galerijeva gamzigradska gradnja sa sačuvanim ostacima ipak stoji znatno bolje od Dioklecijanove.

Dioklecijanova je abdikacija, kako nam to potvrđuju i literarni izvori, bila sastavni dio velikog reformnog programa; bila je smišljen i svjesno proveden čin. O odabiru njezina trenutka može se, dakako, diskutirati. Na Dioklecijanovo i Maksimijanovo mjesto, ustoličeni u svečanim ceremonijama u nazočnosti obojice doskorašnjih vladara, stupili su njihovi cezari. Javno manifestiran čin jasno je i nedvojbeno predstavljao odstupanje s vlasti, uz istodobnu predaju svih vladarskih ingerencija unaprijed predviđenim i javno proklamiranim nasljednicima. Slijedom toga, sasvim je jasno da je takav čin podrazumijevao potpuno odricanje od vlasti u svakom pogledu i na svim razinama. Unatoč tome, prevladava mišljenje kako i Dioklecijan i Maksimijan ni nakon abdikacije ,... nisu bili posve umirovljeni nego su zadržali počasni naslov senior Augustus, koji je uključivao savjetodavnu funkciju. " ${ }^{11}$

Silazak s vlasti i s pozicija moći podrazumijevao je i prestanak mogućnosti raspolaganja golemim financijskim sredstvima, od kojih je pretežit dio bio namijenjen plaćanju brojne vojske, glavnog oslonca vlasti u Rimskome Carstvu, čija je lojalnost i pouzdanost ovisila ponajprije o redovitosti i izdašnosti plaćanja. Carska je blagajna nakon abdikacije prešla u ruke novih vladara. Ne treba pritom smetnuti s uma ni to da su obojica augusta prilikom napuštanja vlasti, a za Dioklecijana je to i izrijekom potvrđeno, bili već ljudi poodmaklih godina. Prema najgrubljoj računici, Dioklecijan je tada imao šezdesetak godina i bio je prilično narušena zdravlja. ${ }^{52}$ Kakvu je važnost u tim uvjetima, u surovu okruženju neprekidne borbe za vlast, mogao imati počasni naslov senior augustus? Uostalom, ako je vjerovati Laktanciju, Galerije je nestrpljivo očekivao trenutak Dioklecijanove abdikacije kako bi se domogao časti augusta i upravo je on izvršio svojevrstan pritisak na ostarjelog cara da odstupi s vlasti. ${ }^{53}$ Svi se literarni izvori slažu u tvrdnji kako je Dioklecijan nakon abdikacije živio kao privatna osoba u svojoj vili kraj Salone. Potpuno odricanje od vlasti, kad to i ne bi izrijekom bilo naglašeno u izvorima, nedvosmisleno potvrđuje podatak kako je car nakon abdikacije odbacio svoje latinizirano carsko ime i ponovno preuzeo ono izvorno - Diocles.

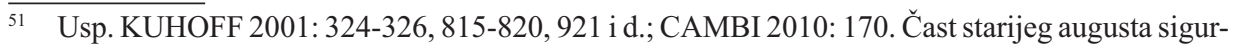
no nije podrazumijevala nikakvu savjetodavnu funkciju, već je to bila isključivo počasna titula. Prihvatljivije je i realnije jedno ranije Cambijevo mišljenje: „Kad se Dioklecijan povukao, on je službeno postao običan čovjek, čak je simbolički vratio i svoje staro ime Diocles, pokazujući time da je opet postao ono što je bio i prije uspona na prijestolje.“ CAMBI 2005: 164.

Lact., DMP: 17.

53 Isto: $18,5$. 
U tom svjetlu trebalo bi, čini se, trezvenije pristupiti i pretpostavljenom carskom ceremonijalu, koji se i nakon careve abdikacije navodno nastavio obavljati u Palači, što je teza za koju se uporno zalagao E. Dyggve ${ }^{54}$, a prihvatio ju je i razradio B. Gabričević. ${ }^{55}$ Činjenica jest da je najreprezentativniji dio građevinskog sklopa svakako bio i ostao Peristil, što je vjerojatno i razlog da je taj prostor u kasnijim stoljećima pretrpio i najmanje promjena u odnosu na svoj prvotan izgled. No, je li njegova funkcija pred ulazom u carev stan trebala nužno biti ceremonijalna? Ako je ikakva carskog ceremonijala i bilo, za što doista nema nikakvih potvrda, on se zacijelo nije vršio na Peristilu, na samom ulazu u Vestibul. Potpuno je nejasno u kojim bi se to prilikama bivši car ondje ukazivao i kome. ${ }^{56}$ Osoblju u Palači ili Salonitancima iz okolice? Koji bi to podanici slobodno ulazili u rezidenciju božanskoga vladara? ${ }^{57}$ Moglo bi se, doduše, pomišljati na oveći dio klijentele, koju je car stekao za života. Čini se pretjeranim pretpostaviti kako nije bilo onih koji se žele pokloniti bivšem caru, onih koji su mu nešto „dužni“, kojima je omogućio stjecanje neke koristi. S druge pak strane, to bi, kad je o klijenteli riječ, moralo podrazumijevati dogovorene i kolektivne dolaske, što je u ondašnjim prilikama malo vjerojatno. Stari pisci donose obilje priča o servilnosti, poglavito u senatorskom staležu, te adekvatan broj onih o napuštanju dojučerašnjih dobročinitelja i prelasku na stranu koja više obećava. Uzevši u obzir ljudsku prirodu, uvjerljivijom se pretpostavkom čini kako je silaskom s trona ostarjeli vladar izgubio najveći dio klijentele. Pa ipak, teško je povjerovati kako bivši car nije imao prisnih prijatelja koji su mu i nakon napuštanja vlasti ostali vjerni. No, bi li se njima ukazivao kao božanstvo u Protironu, a oni pred njim padali u proskinezu? Takvi su se posjetitelji, kojih je svakako bilo, zacijelo primali u privatnu audijenciju i druženje unutar Dioklova stana.

Teza o Dioklecijanovu carskom ugledu i važnoj ulozi u kasnijim zbivanjima te zadržavanju i dijela carskih ingerencija temelji se tek na jednome naoko čvrstom argumentu koji, sagledan iz drugoga kuta, nema tako veliku težinu. Radi se o Dioklovu sudjelovanju na sastanku u Karnuntu 308., u vrijeme duboke krize tetrarhijskog uređenja. ${ }^{58}$ Nema dvojbe da je na savjetovanje Dioklo pozvan kako bi pripomogao rješavanju spora oko prvenstva, iz čega je, čini mi se i suviše olako, izvučen zaključak o njegovoj značajnoj ulozi. Čini se ipak uvjerljivijim da je poziv za pomoć u rješavanju spora bio potaknut isključivo nečim drugim, a to je

\footnotetext{
DYGGVE 1965: 53.

55 GABRIČEVIĆ 1987.

56 RAPANIĆ 2007: 61-63.

57 MARASOVIĆ 2009: 13: „Pretpostavlja se da se tu, u protironu, pod središnjim lukom obavljao taj čin svečanoga careva prikazivana podanicima.“

58 O tome opširnije u KUHOFF 2001: 826-840. Usp: CAMBI 2010: 174-176; Isti 2013: 135.
} 
povratak na vlast njegova prijatelja i bivšeg suvladara Maksimijana ${ }^{59}$, što je bilo suprotno temeljnim principima tetrarhijskog uređenja. Budući da su i Maksimijan, svojim povratkom na vlast, i njegov sin Maksencije uzurpacijom ugrozili tetrarhiju, koja je i tako već bila u krizi, Dioklo je zacijelo pozvan da posreduje ne samo kao utemeljitelj tetrarhijskoga sustava, već kao jedina osoba koja bi doista nepristrano mogla sudjelovati u rješavanju spora u koji izravno nije bila uključena s pozicija vlasti. Teško da je starac ozbiljno načetoga zdravlja ${ }^{60}$ mogao predstavljati autoritet vladaru ili vladarima koji su nastupali s pozicija moći, raspolažući neograničenim novčanim sredstvima i velikom vojnom silom. Sastanak u Karnuntu ponajprije svjedoči upravo o tome da bivši car u stvarnosti ne obnaša nikakvu političku funkciju. ${ }^{61}$ Dioklecijan je, kao i Maksimijan, nosio počasni naslov senior augustus te je Galerije pretpostavljao da bi nazočnost starijeg augusta, kreatora tetrarhije, možda mogla pridonijeti rješavanju duboke krize. Sastanak ,tetrarha“ održavao se od 11. do 18. studenoga 308., ali nije posve sigurno tko je sve od zainteresiranih i osobno sudjelovao. ${ }^{62}$ Nema dvojbe da su bili nazočni Galerije, kao sazivatelj sastanka, i najstariji august po pravu seniorata, Dioklo, čiji je to jedini poznati politički čin nakon abdikacije, te Maksimijan, čiju nazočnost, kao i Galerijevu i Dioklovu, potvrđuje Laktancije. ${ }^{63} \mathrm{~S}$ druge strane, na dogovor sigurno nije pozvan Maksencije kao uzurpator, a vjerojatno ni Maksimin Daja, koji je sve otvorenije od Galerija počeo zahtijevati čast augusta. ${ }^{64}$ No, Maksiminovo se sudjelovanje ne može sa

59 Ako je vjerovati Eutropiju, Breviarium: X, 2, nakon Maksencijeve uzurpacije Maksimijan je pismima nagovarao Diokla da obojica ponovno preuzmu vlast, na što se ovaj uopće nije obazirao.

Prema Laktanciju, DMP: 18, 2, upravo je Dioklecijanova starost bila jedan od razloga koji je naveo Galerije, nagovarajući ga na odstupanje. Nekoliko rečenica dalje $(18,7)$ i Laktancije je za Dioklecijana upotrijebio izraz „umorni starac“, a jednako tako i opisujući sam čin abdikacije $(19,3)$ : „Vojnici bijahu postrojeni; sa suzama se starac obrati vojnicima i priopći im da su njegove snage iscrpljene, da želi spokoj poslije napora, da vlast predaje snažnijim ljudima i da će imenovati druge cezare." Koliko god Laktancije bio pristran, u ovaj opis nemamo razloga sumnjati. Euzebije iz Cezareje (Hist. Eccles.: VIII, 13, 11) navodi kako je Dioklecijan poludio nakon teške bolesti: „Prvoga je od naznačenih spopala zlokobna bolest od koje su vlastitosti njegova uma zapale u ludilo. S onim koji je s njim imo čast drugoga položaja opet je prigrlio obični građanski život.“

61 Na temelju natpisa nađenog u Karnuntu (CIL III: 4413; DESSAU ILS: 659) Cambi (CAMBI 2009: 177-178) zaključuje da su Dioklecijan, Maksimijan i Galerije tada obnašali čast augusta jer se spominju augusti i cezari, iako se nijedno ime ne navodi na samome natpisu, koji glasi: D(eo) S(oli) I(nvicto) M(ithrae) / fautori imperii sui / Iovii et Herculii / religiosissimi / Augusti et Caesares / sacrarium / restituerunt. No, budući da je na spomenutom savjetovanju Licinije proglašen augustom, množina augusti vrlo jednostavno objašnjava dvojicu augusta - staroga Galerija i novoizabranoga Licinija. Maksimijanov naslov augusta nije bio priznavan ni prije sastanka, a ni na tome zasjedanju nije dobio legitimitet. Na kraju krajeva, augusti su, iako stariji, bili i Dioklo i Maksimijan.

BARNES 1996: 32; CAMBI 2010: 177. 
sigurnošću ni isključiti. Uz navedene, sastanku je nazočio još jedan sudionik, Galerijev stari poznanik i suborac Valerije Licinijan Licinije ${ }^{65}$, koji je ustvari bio i najveći dobitnik vijećanja. On je na Galerijev zahtjev proglašen augustom umjesto ubijenoga Severa, a da prethodno nije obnašao čast cezara. ${ }^{66}$ Ako je Dioklo pozvan u Karnunt ponajprije da urazumi svoga nekadašnjeg suvladara i prijatelja, možemo zaključiti kako je njegova misija bila potpuno neuspješna, a eventualan autoritet više nego dvojben. Nisu ga, naime, poslušali ni Maksimijan ni Maksencije. Glavnu je pak riječ na zasjedanju vodio Galerije, a ne Dioklo. ${ }^{67}$ Galerije je bio prokušan vojnik, dokazano sposoban i iskusan vojni zapovjednik, karakterno autoritarna osoba te sposoban upravljač $s$ autoritetom i dugogodišnjim iskustvom $u$ obnašanju vlasti. Da se Galerije nije odlikovao tim kvalitetama, teško da bi ga Dioklecijan bio odabrao i 293. imenovao cezarom. I novoproglašeni cezari nakon Dioklecijanove i Maksimijanove abdikacije bili su ustvari Galerijev izbor, baš kao i na karnuntskom sastanku imenovani august - Galerijev zemljak i stari prijatelj Licinije. Da je Galerijev autoritet bio dvojben, teško da bi on uspio nametnuti Licinijevo imenovanje za augusta bez prethodnog obnašanja cezarske časti. Nije lako povjerovati ni da bi osoba Galerijevih karakternih osobina tražila savjete ili pomoć od umorna i bolesna starca. Kad bi, uostalom, Dioklecijanov autoritet bio neupitan, malo je vjerojatno i da bi se on, kao kreator tetrarhije, suglasio s tim Licinijevim imenovanjem. $\mathrm{Na}$ kraju krajeva, carski je autoritet ponajprije proizlazio iz raspolaganja vojnom silom i financijskim sredstvima, a te su stavke bile pod Galerijevom, a ne Dioklovom kontrolom. I na kraju, da se radilo o ikakvu vrhovnome Dioklovu autoritetu, takva bi se konferencija tada zacijelo sazvala i održavala u njegovoj rezidenciji kraj Salone, odredištu znatno lakše dostupnome svim sudionicima i ambijentu mnogo ugodnijeg okružja od vojnog logora na dunavskoj granici.

Još jedan, u hrvatskoj historiografiji zanemaren, detalj govori u prilog tvrdnji da je bivši car doista nosio samo počasni naslov bez ikakvih ovlasti, a to je pojava njegova carskog imena na konzulskim listama. ${ }^{68}$ Očito je kako mu je Galerije,

$\overline{65}$ Lact., DMP : 20, 3; Eutrop., Breviarium: X, 4.

66 Euseb., HE VIII: 13, 14.

67 KUHOFF 2001: 832; Hieron., Chron. s. a. 308. „Licinius a Galerio Carnunti imperator factus“. Drukčije CAMBI 2010: 178, koji smatra: „Nedvojbeno je da je Dioklecijan u Karnuntu bio glavni arbitar jer je Galerijev autoritet znatno oslabio neuspješnom vojnom protiv Maksencija.“ No, teško da će to biti tako jer literarni izvori beziznimno navode kako je Licinija imenovao upravo Galerije, koji je očito imao dovoljno moći da provede svoju volju. I to je imenovanje provedeno u suprotnosti s principima tetrarhijskog uređenja i slijeda časti, a Dioklo je poštovao Galerijevu odluku, ma što god osobno o tome mislio. Usp. CAMBI 2013: 135.

68 Hydat., Fasti, s. a. 308. „Item Decies et Maximiano VII [Al. Maximiano IX]. His conss. quod est Maxentio et Romulo, levatus Licinius Carnunto III id. Nov."; Prosperi Tironi Epitomae Chronicon., s. a. 308, „Diocletiano X et Maximiano VII. Licinius a Galerio Carnunti imperator factus. "; Consular. constantin., s. a. 308. ,item decies et Maximiano; Fasti vind. prior, s. a. 308. Dioklecijanov deseti konzulat na margini navodi samo BELAMARIĆ $1998^{2}$ a: 12. Usp. i SCARRE 
da bi Dioklu kao privatnoj osobi dao legitimitet i politički autoritet, 308. dodijelio konzulsku čast, čime je njegovu sudjelovanju na karnuntskom sastanku dao pravnu podlogu.

Upravo stoga što su svi sačuvani literarni izvori suglasni s tvrdnjom da je Dioklecijan nakon abdikacije živio kao privatna osoba u svojoj vili kraj Salone, čvrstog sam uvjerenja kako ne postoji baš nijedan valjan argument koji bi davao ikakva povoda mišljenju kako je Dioklo zadržao bar djelić vladarskih ingerencija, pa makar i savjetodavnu ulogu, osim naslova senior Augustus. ${ }^{69} \mathrm{U}$ tom slučaju Dioklecijanova nam se palača ukazuje tek kao „Residence of a retired Roman emperor“", kako je svoju knjigu naslovio i J. J. Wilkes ${ }^{70}$, ili Palača za cara „penzionera“, kako je pomalo duhovito jedno poglavlje nazvao Ž. Rapanić. ${ }^{11} \mathrm{U}$ prilog Dioklecijanovu ugledu na prvi pogled mogla bi govoriti njegova deifikacija. No, još od proglašenja Julija Cezara božanstvom post mortem, deifikacija vladara bila je čisto politički čin i ustaljena praksa, pa je većina rimskih careva nakon smrti divinizirana, što se pretvorilo u običaj. Ta čast nije ukazana samo onima koji su osuđeni na damnatio memoriae ili su bili neizrecivo mrski i nepopularni vladari. ${ }^{72}$ Dioklecijanov je slučaj bio nešto što odskače od uobičajenoga modela. Na prvome mjestu, bio je samoproglašeni bog od početka svoje vladavine (dominus et deus). Potom je svojevoljno abdicirao s vlasti, pa je bio i ostao bivši, ali još uvijek živ, vladar. To je bio problem s kakvim se ni rimski Senat ni nasljednik carske vlasti dotad nisu susreli. No, ni carska čast više nije bila jedinstvena jer ju je obnašalo više međusobno suprotstavljenih osoba jednakih ambicija. Dioklecijan se nije otvoreno zamjerio, niti je bio prijetnja ikojem od tadašnjih careva (Konstantin, Licinije, Maksimin Daja). ${ }^{73}$ Kako postupiti nakon Dioklecijanove smrti? Presedan je, dakle, i u abdikaciji, ali i u postupanju s umrlim bivšim vladarom. Bio je bivši car, a Konstantinu (tada na vlasti na Zapadu i u Italiji) Dioklecijanova apoteoza

1995: 197 s identičnom greškom. Prilikom abdikacije Dioklecijan je, naime, konzulat obnašao devet puta, pa mu puni naslov prilikom abdikacije nije mogao biti Consul X, nego Consul IX.

Drukčije KUHOFF 2001: 744, koji zastupa tezu kako je stariji august ostao član vladajućeg kolegija, u sklopu kojeg je imao važnu ulogu, što navodno jasno pokazuju natpisi, kovanice i slikovni prikazi iz tog vremena. Nije, međutim, jasno o kojem bi se to carskom kolegiju radilo i kakva je to važna Dioklecijanova uloga. Osim karnuntskog sastanka, nije poznat nijedan drugi Dioklov politički čin. Natpisi i kovanice pak ne navode ništa drugo doli Dioklecijanove počasne titule. Bivši je vladar bio živ i nije ga bilo moguće ne navesti. 
nije smetala. Dapače, sam Konstantin u to vrijeme još nije imao precizno definiranu politiku i kolebao se između kršćanstva i poganstva.

Polazeći od analize literarnih izvora, jedini opširniji opis careve abdikacije potječe iz Laktancijeva pera. Nakon što je skinuo purpur i ponovno postao Dioklo, stari se car proveze kolima kroz grad i zaputi u domovinu. ${ }^{74} \mathrm{O}$ tome tko je sve putovao s bivšim carem kod Laktancija nema spomena, ali nije moguće da bi takav put $u$ ono vrijeme bio zamisliv bez oružane pratnje. Koliko je ona bila brojna, o tome možemo samo nagađati. S Dioklom je nedvojbeno morala putovati i njegova osobna posluga, vjerojatno robovi, te poneki osobni tajnik i pokoji povjerenik (možda blagajnik), ali teško da ima osnova za predalekosežne zaključke, poput onog da je s njim ,...putovala i skupina odabranih suradnika..." ${ }^{\text {"75 }} \mathrm{Nije}$, naime, jasno u čemu bi to oni s bivšim carem surađivali. Nema spomena ni o Dioklovoj supruzi Priski, ali dopustimo pretpostavku da su zajedno putovali u novi dom, utvrđenu vilu na dalmatinskoj obali nedaleko od Salone.

Već su prvi istraživači Palače zaključili kako ona ima nekoliko sadržaja, očito unaprijed nužno zadanih projektom i namjenom građevine. Ona tako ima rezidencijalni prostor (luksuzni dio, stan i manje termalne komplekse), sepulkralni i religijski (Mauzolej, hramovi), smješten južno od dekumana, i cijeli sjeverni dio namijenjen, kako se pretpostavlja, posluzi i boravku dijela oružane pratnje tj. vojnog osiguranja Palače. Takav je raspored izrazito jednostavan i vrlo logičan jer dijeli prostor unutar zidina na dvije polovice. Duboko dvojim da su Dioklecijanovi arhitekti razmišljali u kategorijama: sepulkralno, religijsko, rezidencijalno ili propagandno. Najvjerojatnije su od cara dobili konkretnu zadaću, smjernice i sadržaje kojima su morali udovoljiti i taj su zadatak, ne treba dvojiti, izvršili najbolje što su znali. Pitanje je li Dioklecijan osobno izabrao poziciju za gradnju Palače, sigurno je, nikad neće dobiti odgovor. Po mome skromnom mišljenju, nije. Koliko danas znamo, Dioklecijan kao car nikada nije bio u Saloni ${ }^{76}$, a ako nakratko i jest, veliko je pitanje bi li i zbog čega prolazio kroz salonitanski ager sve do morske obale. Ta Dioklecijan je tijekom dvadesetogodišnje vladavine svega jednom nakratko bio u Rimu, a cijeli zapadni dio države prepustio je na upravu Maksimijanu. O brojnim problemima i krizi uprave svjedoči i dioba vlasti i stvaranje tetrarhijskog sustava, pa je malo vjerojatno da bi car imao vremena

$\overline{74}$ Lact., DMP $:$ 19, 6. Laktancije je upotrijebio imenicu rex (veteranus rex), umjesto imperator ili augustus. No, korijen imenice rex, koja je uopćeno poprimila značenje „kralj“, ima općenitije značenje upravljanja, vladanja (rego 3.-xi, -ctum; regimen, -inis, n.), dakle „stari vladar“. Dakako, imenica rex u latinskom je jeziku imala i pejorativno značenje, pa se ne može isključiti ni mišljenje da je Laktancije ostarjelog augusta htio i dodatno poniziti, prikazujući ga kao nasilnog vladara, što i inače čini kroz cijeli tekst.

75 RAPANIĆ 2007: 64.

76 BELAMARIĆ 2004: 31 i bilj. 69. 
tražiti pogodnu lokaciju za svoju vilu, tim prije ako je, u čemu se slažu gotovo svi autori, odluka o gradnji Palače donesena tek nakon 293.

Odabir lokacije za gradnju Palače nastojalo se dovesti u čvrstu vezu sa središnjim položajem u odnosu na carske rezidencije tetrarha: Trier, Mediolan, Sirmij, Tesaloniku i Nikomediju te Rim, koji više nije bio političko središte. ${ }^{77}$ Nije nimalo jasno kakvu bi ulogu u svladavanju krize trebala imati blizina umirovljenoga cara ijednoj od rezidencija tetrarha, a posebice blizina Rimu, kojemu tijekom svoje duge vladavine Dioklecijan nije posvećivao ikakvu pozornost. ${ }^{78}$ Ta teza, naravno, podrazumijeva uvjerenje da je bivši car još uvijek bio jamstvo za održavanje tetrarhije. No, takvo mišljenje u potpunosti opovrgavaju kasniji događaji. Tetrarhijski je sustav zapao u krizu već vrlo brzo nakon Dioklecijanove abdikacije, ali s njegove je strane izostala ikakva reakcija. Jedini njegov posvjedočen čin jest sudjelovanje na sastanku u Karnuntu, ali ni taj nije on osobno inicirao. Da je imao volje i interesa, ikakva političkog utjecaja, vojne snage, pa i tjelesne energije, stariji august vjerojatno bi promptno i osobno reagirao čim je tetrarhijski sustav doživio prvu veliku krizu, do koje je došlo nakon Konstancijeve smrti 25. srpnja 306. Nakon toga krizne su se situacije redale jedna za drugom, ali nijedna Diokla nije potaknula na djelovanje. Bez ikakve je reakcije tako protekla Maksencijeva uzurpacija u Rimu 28. listopada 306., Maksimijanov povratak na vlast, Severova neuspjela vojna intervencija u Italiji početkom 307. i potom njegovo pogubljenje 16. rujna iste godine..$^{79}$ Pritom ne treba smetnuti s uma kako je upravo Severa Dioklecijan imenovao cezarom prilikom vlastite abdikacije. Dioklo se nije oglasio ni kad su Maksimijan i Maksencije na razinu augusta uzvisili Konstantina, čim se ovaj potkraj ljeta 307. vjenčao s Maksimijanovom kćeri Faustom, a jednako tako nije se odlučio oglasiti ni kad je Galerije osobno doživio težak neuspjeh prilikom vojnog pohoda na Italiju i Rim. Čak ni kad je bila neposredno ugrožena

CAMBI 1997: 42-43; Isti 2005a: 164: „Dioklecijan za svoje prebivalište nakon abdikacije nije odabrao Italiju, ali ni Malu Aziju, gdje je proveo svoj vladarski vijek. Nije želio biti tik uz mjesta direktnog odlučivanja, ali isto tako ni puno daleko. Želio je ipak motriti što se događa. U slučaju previranja živi je vladar još uvijek jamstvo za održavanje tetrarhije. Takvim zahtjevima najpogodnije mjesto za počinak bila je Dalmacija, careva domovina. Ako se pogleda karta Carstva, može se vidjeti da je ona gotovo u samom središtu kruga koji zatvaraju carske rezidencije tetrarha: Trier, Milano, Sirmij, odnosno Tesalonika i Nikomedija. Ne bijaše daleko ni Rim, još uvijek kulturno, iako ne više i političko središte, čije se bilo uvijek moralo opipavati." Kasniji politički događaji i krize tetrarhijskog sustava u potpunosti opovrgavaju tu tvrdnju. Cijela se Dalmacija, ne samo Salona, nalazila u središnjem dijelu Carstva i s Dioklecijanom i bez njega. Odabir lokacije za gradnju Palače s time sigurno nije imao nikakve veze.

78 Najmonumentalnija gradnja u Rimu, pripisana Dioklecijanu, jesu terme, ali njih nije dao graditi Dioklecijan, već Maksimijan, koji ih je posvetio Dioklecijanovu imenu, kako to proizlazi iz posvetnog natpisa pronađenog u termama $(C I L$ VI: $1130=31242)$. Gradnja je otpočela nakon Maksimijanova povratka iz Afrike ujesen 298., a dovršena je tek nakon Dioklecijanove i Maksimijanove abdikacije blagonaklonošću Galerija i Konstancija.

Anon. Vales. pars prior: 4, 10. 
njegova vlastita obitelj, ostarjeli bivši car nije bio u mogućnosti poduzeti ikakav konkretan potez, već je morao nemoćno promatrati potpunu propast i vlastite supruge i kćeri jedinice Valerije. Kad bi se kriterij potencijalne lokacije za Palaču određivao blizinom carskih rezidencija tetrarhâ i kad bi to imalo ikakve veze $\mathrm{s}$ autoritetom bivšeg cara, sastanak tetrarhâ u tome bi se slučaju posve sigurno održavao u Dioklovoj palači, a ne u Karnuntu.

Teško je, međutim, zanijekati prilično prisan uzajaman odnos Salonitanaca i Dioklecijana, koji se vrlo jednostavno može protumačiti pragmatičnim razlozima. Za potrebe careve nove gradnje, pri čemu podrazumijevam i akvedukt i Palaču, Salona se nedvojbeno morala odreći dijela svog agera ${ }^{80}$, kako prostora buduće Palače i tamošnjih već postojećih građevina ${ }^{81}$, tako i dijela zemljišta na trasi novoga akvedukta. Ne treba zaboraviti i činjenicu da je na tako opsežnim radovima i velik broj Salonitanaca na dulje vrijeme mogao računati na poslove i zaradu, što u uvjetima tadašnje gospodarske krize nije bilo zanemarivo. Ondašnji su prosperitet i obnova Salone, uostalom, i arheološki posvjedočeni. ${ }^{82}$ Realno je pretpostaviti da se za eventualne materijalne gubitke pojedinih Salonitanaca car financijski sigurno odužio jer mu nije moglo biti u interesu da nedaleko od svoga boravišta ima brojne nezadovoljne građane. $U$ prilog tome govori promjena imena grada u Colonia Valeria Martia Salona Felix. ${ }^{83}$

Gradnja je svakako ostala ne sasvim dovršena. ${ }^{84}$ Prevladavajuće je mišljenje da je razlog tome carev prijevremen dolazak u Palaču, zbog čega bi, navodno, radovi bili prekinuti. ${ }^{85}$ Međutim, razlozi vidljive nedovršenosti palače u nekim dijelovima, osobito u skulpturalnom ukrasu, mogli bi biti i mnogo prozaičniji. Radove je, naime, trebalo plaćati, što, naravno, nije bio problem dok je Dioklecijan raspolagao carskom blagajnom. Ne treba dvojiti da je car prije abdikacije spremio sa strane značajna financijska sredstva, no ona nisu mogla trajati neograničeno. Pomoćna radna snaga i obični radnici, dijelom robovi, a ni zidari nisu toliko skupi, ali vrsne majstore-umjetnike trebalo je dobro platiti. ${ }^{86}$ Iako započet kao carska gradnja, nakon abdikacije još nedovršen objekt postao je privatno vlasništvo, čije se ukrašavanje nije financiralo državnim sredstvima.

80 CAMBI 2005b: 164; BASIĆ 2012: 24.

81 BASIĆ 2012: 17-18. U supstrukcijama Palače otkriveni su ostaci i tragovi prilično raskošnih građevina, a jednako tako i u neposrednoj blizini, u Manušu. BUŽANČIĆ 2011: 13-14.

82 JELIČIĆ RADONIĆ 2011: 22.

83 CAMBI 2005b: 164.

84 Drukčije KUHOFF 2001: 745.

85 CAMBI 2005b: 163-164; MARINKOVIĆ 2010: 244; Isti 2014: 300-301.

86 U očuvanim reljefnim ukrasima Palače može se razlikovati doprinos vrsnih majstora s Istoka, nasuprot djelima domaćih lokalnih klesara. CAMBI 2002: 181; LONGAE SALONAE 2002: 141-143. 
Mjesto ipak iziskuje vrlo kratak osvrt na skulpturalni ukras tetrarhijske propagande. Upada u oči kako je u Palači preživio upadljivo mali broj skulptura ${ }^{87}$, iako bi ih se ondje, po prirodi stvari, izvorno trebalo nalaziti mnogo. Beziznimno se to pripisuje temeljitoj purifikaciji palače od poganskih simbola nakon pobjede kršćanstva i tijekom kasnijih stoljeća. ${ }^{88} \mathrm{~S}$ druge pak strane, skulpturalni ukras hramova i njihova dekoracija odlično su očuvani. U cijeloj Palači, osim sačuvanih portreta Dioklecijana i njegove supruge Priske u medaljonima unutrašnjeg friza mauzoleja, nađene su samo dvije glave uzidane u zid palače Cambi u blizini Zapadnih vrata ${ }^{89}$ te još jedna, s otučenim licem, uzidana u zid srednjovjekovne kuće u neposrednoj blizini Vestibula..$^{90} \mathrm{U}$ blizini Sjevernih i Istočnih vrata nisu pak nađeni nikakvi ostaci skulptura. Na Sjevernim, najraskošnije ukrašenim vratima, kao uostalom i na ostalima, pretpostavljen je tetrarhijski skulpturalni propagandni program ${ }^{91}$, kakav je potvrđen i u Galerijevoj gamzigradskoj palači s prikazima šestorice vladara. Želimo li povlačiti ikakve paralele, onda je potpuno jasno da bi isti takav ideološki program trebalo očekivati i u Dioklecijanovoj palači. Budući da u Gamzigradu nedostaje Jupiter, prikazan kao zaštitnik tetrarhije, logično je pretpostaviti da ni ponad Zlatnih vrata na najvišem sačuvanom postolju ne bi trebalo očekivati Jupitera. Upravo suprotno, umjesto pet, trebalo bi očekivati šest postamenata od kojih danas nedostaju dva - jedan od dvaju najvećih i jedan srednje visine. Vrlo je vjerojatno da skulpture koje su bile predviđene na mnogim mjestima u Palači nikad nisu ni bile postavljene jer, po prirodi stvari, kipovi i portretna plastika postavljaju se posljednji, tek kad su građevinski radovi potpuno dovršeni, a oni to nikad nisu bili. ${ }^{92}$ Teško je pomisliti

87 MARINKOVIĆ 2014: 292-293. 
da se bivši car uselio u rezidencijalni dio u kojem se još čula buka klesara, pa je po svoj prilici carev stan do trenutka useljenja bio potpuno dovršen i zacijelo ukrašen predviđenim skulpturama, koje su se i onako izrađivale ili opljačkale negdje drugdje. To, uostalom, potvrđuju i očuvani ostaci mozaičke dekoracije. ${ }^{93}$ Ostatak kompleksa vjerojatno je ukrašen tek djelimice ili je ostao bez skulptura. Kad bi se doista nedostatak skulptura moglo protumačiti isključivo nedvojbenom purifikacijom u doba prevlasti kršćanstva, onda bi unutar Palače trebalo očekivati i mnogo veći broj nalaza fragmenata. Takav je primjer s egipatskim sfingama, čiji su se brojni fragmenti, uz nekoliko cijelih primjeraka, sačuvali unutar i oko Palače. ${ }^{94} \mathrm{U}$ tom bi slučaju stradali i mnogi drugi skulpturalni ukrasi, primjerice oni na konzolama i teatarske maske. ${ }^{95}$

Na kraju, trebalo je izdržavati i prateće osoblje u Palači i plaćati vojnu posadu. ${ }^{96} \mathrm{O}$ sigurnosti bivšega cara nedvojbeno se nisu brinule regularne carske trupe, već privatne plaćene postrojbe (buccelarii), kakve su u ondašnjim prilikama izdržavali brojni moćnici diljem Carstva. Broj plaćenika u Palači nije mogao biti osobito velik ${ }^{97}$, a nije ni trebao biti. Zidine Palače već i svojim fortifikacijskim obilježjima (veliki lučni otvori u zidinama sa svih triju kopnenih strana, kao i nad svim kopnenim vratima) nisu mogle biti namijenjene u prvome redu obrani, već prije zaštiti od naoružanih razbojničkih skupina ili pobunjenih kolona i robova. ${ }^{98}$

93 O tome usp. MATULIĆ 2004; MARINKOVIĆ 2014: 292 i bilj. 2.

94 CAMBI 2005b: 168. Usp. SELEM 2008: 158-170. O tome opširnije TADINAC 2011. Do sada je pouzdano potvrđeno postojanje 12 sfingi unutar palače, a zacijelo ih je bilo više. Cambijev zaključak kako njihova poruka u kasnije kršćansko vrijeme uopće nije smetala jer se nije razumjela nije utemeljen jer se na gotovo svim primjercima uočava namjerno odbijanje glave, a na većini je otučen ureus. MARINKOVIĆ 2014: 294 i bilj. 9.

95 Očit je primjer Viktorija na zaglavnom kamenu Zapadnih vrata. O tome opš. CAMBI 1981: 6 i d. Usp. također CAMBI 2002: 175-176 i bilj. 779; Isti 2005b: 167, sl. 244; TADINAC ŠEĆER 2013: 383 i bilj. 9 i 10. Cambijeva tvrdnja kako zamjena Viktorije (Nike) križem s kristijanizacijom Palače nema nikakve veze nije prihvatljiva. Ako su, naime, oba simbola carska, onda uistinu nije bilo potrebe da se stariji mijenja novim, niti bi se pripadnost Palače carskoj vlasti na taj način jasnije ocrtavala. Carska je vlast ionako bila vrlo daleko od provincijske palače i zauzeta mnogo većim problemima da bi se bavila carskom simbolikom Zapadnih vrata. Između ostalog, ni sam proces preklesavanja nije bio ni jednostavan ni jeftin, niti ga se moglo povjeriti bilo kome.

96 Cambijeva je pretpostavka da je nakon abdikacije bivši car ,...morao biti okružen brojnim službenicima, služinčadi, robovima, majstorima, eunusima i sl. te njihovim obiteljima. To bijaše velika obitelj, čiji je pater familias bio bivši car." CAMBI 2010: 172.

97 CAMBI 2010: 172 i bilj. 17, pretpostavlja da je Palaču i Diokla štitila „... barem jedna veksilacija s danas teško odredivim brojem pješaka, konjanika i zapovjednog osoblja." Kakva bi bila funkcija konjaništva u zaštiti Palače nije baš sasvim jasno.

98 NIKŠIĆ 2012: 219. O neprikladnosti i nepouzdanosti fortifikacija neporecivo govori činjenica kako su i Zlatna i Srebrna vrata već u ranome srednjem vijeku zazidana, baš kao i lučni otvori nad njima. Već potkraj 5. ili početkom 6. stoljeća u stražarskom hodniku ponad Zlatnih vrata ugrađena je crkvica posvećena sv. Martinu. Jednako su tako bili zazidani i veliki lučni otvori u zidinama sa svih triju kopnenih strana. 
Teško da bi, kako to navodi Cambi, mogle zaštititi cara od ,potencijalnih uzurpatora vlasti ${ }^{\text {“99 }} \mathrm{i}$ to sigurno nije ni bila njihova namjena. Ponajprije stoga što je car već abdicirao, pa mu vlast nitko ne bi ni mogao uzurpirati, a zatim i stoga što je potencijalna uzurpacija, kako to pokazuju brojni primjeri, bila neprovediva bez podrške većih vojnih postrojbi. Pred pretpostavljenim naletom nekoliko tisuća vojnika, opremljenih bojnim spravama, Palača bi vrlo brzo pala sve kad bi plaćenici koji je brane i ostali lojalni svome gospodaru, što je ipak malo vjerojatno. Ukoliko Palača nije imala i funkciju vojnog logora, posve je nejasno zbog čega bi posada oružanika koji su je štitili uopće izvan službe boravila unutar zidina i ondje morala imala trajni smještaj i prehranu. Na kraju krajeva, većina je careva, koji su nasilno izgubili život, ubijena bez obzira na brojnu osobnu zaštitu.

Do sada potpuno zanemareno ostalo je i pitanje sredstava za carev život i svakodnevne potrebe. Jesu li stariji augusti uživali određenu godišnju apanažu iz državne blagajne? U literarnim izvorima o tome nema spomena ni naznaka. Jesu li se u salonitanskom ageru nalazili neki zemljišni posjedi u Dioklovu vlasništvu? Izvori o tome šute, ali je odgovor vjerojatno potvrdan. Je li bivši car doista vlastitom rukom uzgajao povrće? ${ }^{100} \mathrm{Za}$ bolesna čovjeka u poodmaklim godinama života, koji je usto cijelu karijeru proveo kao vojnik, vojskovođa i vladar, to se čini malo vjerojatnim. No, umirovljeni car morao je imati nekakav siguran stalni izvor prihoda. To se pitanje u znanstvenoj literaturi, koliko je to meni poznato, do najnovijeg vremena uopće nije postavljalo, a ako gdjegdje i jest, onda ono nije potaknulo ikakvo daljnje zanimanje. Mislim da se ono vrlo lako rješava dobro argumentiranim mišljenjem J. Belamarića o gineceju u Palači ${ }^{101}$, što bi značilo da je bivši car pod stare dane odlučio postati poduzetnik, a ne ratar. Belamarićevu je tezu novim uvjerljivim argumentima nedavno osnažio i G. Nikšić. ${ }^{102}$

$99 \quad$ CAMBI 2005a: 164.

100 Poznata epizoda kojom se oslikava Dioklovo odbijanje prijedloga o ponovnom preuzimanju vlasti sasvim je sigurno tek anegdotica, koja nema puno veze sa stvarnošću.

101 BELAMARIĆ 2004: 5-42. Belamarićeve je argumente pokušao osporiti Ž. Rapanić, ali sa stajališta kako je Palača luksuzna carska rezidencija i istodobno prostor tetrarhijskog, dvorskog, imperijalnog i božanskog okruženja, što ona zacijelo nikad nije bila. Neki od njegovih protuargumenata pak govore u prilog Belamarićevoj tezi, posebice kad navodi legije, kohorte i ale, koje su se i u kasnije vrijeme zvale Herculia, Maximiana, Diocletiana, Nova Diocletiana. Međutim, one ta imena nose po vladarima koji su ih osnovali u vrijeme kad rimska vojska postaje sve većom. Budući da legije zadržavaju imena svojih careva osnivača, tako je i ginecej zadržao ime svog utemeljitelja, bez obzira na pobjedu kršćanstva. I drugi Rapanićev protuargument otpada jer se tvrdnja kako je „...nespojiva funkcija carske palače-ljetnikovca...s bilo kakvom industrijom, manufakturom i proizvodnjom“, pogotovo s neugodnim mirisima, teško može braniti, s obzirom na unutarnji raspored prostora u Palači. Carev je stan, koji obuhvaća tek četvrtinu Palače, prema njezinim unutarnjim prostorima potpuno zatvoren, a u odnosu na pretpostavljen proizvodni dio, također zatvoren, izdvojen je i religijski prostor okružen temenosom, kojemu se, kao i Dioklovu stanu, pristupalo samo s Peristila.

102 NIKŠIĆ 2012. 
Ginecej u Palači potvrđen je navodom u Notitia Dignitatum ${ }^{103}$ s karakterističnim predikatom Iovensis, koji se može dovesti u vezu jedino sa samim Dioklecijanom, to jest s njegovim apelativom Iovius. Iako su ga nosili i Galerije, Maksimin Daja i Licinije, Palača je ipak bila usko vezana samo uz Dioklecijana. Eventualnom kasnijem smještaju gineceja u Palaču, u vrijeme nakon Dioklove smrti, protivi se istodobnost izgradnje akvedukta, koji je Palaču opskrbljivao vodom, i same njezine gradnje, a jednako tako i kapacitet Dioklecijanova akvedukta, koji je umnogome nadmašivao kapacitet onoga koji je vodom opskrbljivao susjednu Salonu. Iako još uvijek nije pouzdano poznato na kojem je točno mjestu akvedukt ulazio u Palaču, kanalizacijski sustav otkriven u njezinu sjevernom dijelu dopušta pretpostavku da je približno ista količina vode koja je dotjecala akvedutom i ulazila unutar zidina. Doduše, za navedeni ginecej nisu nađene čvršće i nedvojbene arheološke potvrde ${ }^{104}$, ali sjeverni je dio Palače ionako najslabije sačuvan. No, arheoloških potvrda unutar zidina nije nađeno ni za tetrarhijski kult, dok je ginecej ipak izravno potvrđen jednim literarnim izvorom i to tekstom službenog karaktera.

Nije naodmet pitanje carevih prihoda detaljnije razraditi, oslanjajući se na Belamarićevu recentnu reinterpretaciju, kako vrela i rezultata arheoloških istraživanja, tako i novog tumačenja arhitektonskog projekta i izvedbe građevine. Kao pragmatičan čovjek, Dioklecijan je vjerojatno brižno promislio o životu nakon planirane abdikacije. No, i opće okolnosti, dok je još bio na vrhuncu vlasti, išle su mu na ruku. Naime, uspostavom tetrarhije rimska se vojska neizmjerno povećala, što izrijekom navodi i Laktancije ${ }^{105}$, a tako povećan broj vojnika trebalo je ne samo plaćati, nego i opskrbiti bojnom opremom i odijelima. Mišljenja sam da je upravo ovdje Dioklecijan vidio priliku i da je Palača osmišljena kao utvrđena carska radionica, ginecej, u kojoj je njezin vlasnik imao i luksuzno uređeno boravište, kako je to nedavno i obrazloženo. ${ }^{106}$ Tek u tom kontekstu moguće je povući i usporedbu s Galerijevom utvrđenom

103 Not. Dig. Occid.: XI, 46.

104 BELAMARIĆ 2004: 28: „Postoji niz neatraktivnih arheoloških tragova karakterističnih za ginecej, koje konvencionalna arheologija, u splitskim poslijeratnim desetljećima, nije smatrala dostojnim inspekcije." NIKŠIĆ 2012: 225 i bilj. 14. Nalazi plitkoga bazena, poda s jednostavnim bijelim mozaikom i prostorije sa stijenkama, obloženim hidrauličkom žbukom, tada interpretirani kao „kasnoantičke intervencije“, pružaju dovoljno argumenata da ih se interpretira kao dijelove proizvodnog kompleksa. Tome u prilog govori i pronađen ostatak malog odvodnog kanala, koji je otkriven prilikom sondiranja 2005., kada nisu otkriveni tragovi monumentalnog pločnika, već samo skroman pod od tegula i kamenih ploča.

105 Lact., DMP: 7, 2. „Uzdigao je još tri sudionika u vlasti, pošto je čitav svijet podijelio na četiri dijela, povećao vojsku, jer je svaki od njih nastojao posjedovati veći broj vojnika od onoga što su ga posjedovali prijašnji carevi koji su državom vladali sami.“"

106 BELAMARIĆ 2003; Isti 2004; NIKŠIĆ 2009; Isti 2012. 
palačom u Gamzigradu. ${ }^{107} \mathrm{O}$ tome je li Dioklecijan namjeravao pokrenuti proizvodni proces i prije abdikacije, što bi mogao biti jedan od razloga za užurbanu gradnju, ili je do abdikacije zbog bolesti ${ }^{108}$ došlo ranije od planiranog trenutka, može se samo nagađati. U svakom slučaju, početak proizvodnje u Dioklecijanovu gineceju nije poznat ${ }^{109}$, ali je do njega po svoj prilici došlo tek nakon napuštanja vlasti.

Nakon Dioklove smrti Palača je postala carski posjed, na što je već ukazao F. Bulić. ${ }^{110}$ Dioklo je umro bez zakonitih nasljednika, ali kad i ne bi bilo tako, ginecej unutar zidina, u to vrijeme jedini u Dalmaciji, zacijelo bi bio ekspropriran u ime carskoga fiska, što se možda dogodilo već i potkraj života njegova vlasnika. $\mathrm{U}$ isto vrijeme u Palači dolazi i do prvih promjena, izazvanih jednim dijelom mijenjanjem službenoga stava prema kršćanstvu nakon Galerijeva edikta 311., a djelomice i vjerojatnom potrebitom prenamjenom u južnome dijelu Palače, nekadašnjem Dioklovu intimnom prostoru. S obzirom na temeljitu purifikaciju građevine u stoljećima nakon pobjede kršćanstva, u kojoj je stradala ponajprije skulptura, o tom je dijelu teško išta konkretnije kazati. No, arheološka potvrda ranih graditeljskih intervencija nazire se u zapadnim termama. Postoje čvrste indicije da one nisu bile dio izvornog graditeljskog sklopa Palače ${ }^{111}$ i vjerojatno bi mogle biti posljedica preinaka izazvanih redistribucijom potreba novih stanovnika u nekadašnjem carevu stanu. Do pregradnji i adaptacija zacijelo je došlo i unutar nekadašnjih Dioklovih prostorija, o čemu zbog izrazito loše sačuvanih dijelova nije moguće donositi zaključke.

Zbog šutnje literarnih vrela teško je išta preciznije reći o eventualnim promjenama i životu u Palači tijekom 4. stoljeća. Jedino što se može smatrati nedvojbenim jest da ona tada nema funkciju carske rezidencije. Većina se autora slaže da je u to vrijeme djelovao ginecej, iako neki smatraju da nije nužno trebao biti smješten unutar zidina. To je mišljenje ipak teško braniti jer je akvedukt glavninu vodoopskrbe dovodio u Palaču, kako pokazuju odvodni kanali u njezinu sjevernome dijelu. No, da je život u Palači u 4. stoljeću bio prilično dinamičan, potvrđuju nalazi lončarije, kako one fine, crvene, sjevernoafričke

\footnotetext{
107 NIKŠIĆ 2012: 226 i bilj. 17. „Kao što je Dioklecijan miran život u mirovini osigurao unosnim monopolom u izradi vojne odjeće, njegov zet i posinak je ekonomsku osnovu za financiranje svojega skupog života kao penzioniranog cara okruženog dvorskom raskoši pronašao u proizvodnji željeza i izradi oružja za vojsku. Romulijana je podignuta na strateški i gospodarski važnom položaju u blizini limesa prema barbarskim plemenima, u središtu područja koje je obilovalo rudnicima željezne rude i kovnicama oružja, kao arhitektonski izraz carske veličine i njegova prava na upravljanje tim značajnim izvorima prihoda.“

108 Lact., DMP: 17, 3-9; Eutrop., Breviarium: IX, 27.

109 BELAMARIĆ 2004: 31.

110 BULIĆ I KARAMAN 1927: 181; JOVIĆ GAZIĆ 2011: 167 i bilj. 63.

111 PEROJEVIĆ, K. MARASOVIĆ I J. MARASOVIĆ 2009: 88-90.
} 
produkcije, tako i amfora, svjetiljki, stakla i novca, od čega se velik dio sa sigurnošću može pripisati razdoblju nakon Dioklecijana u 4. stoljeću. ${ }^{112}$ Nalazi novca i veće količine fine keramike potvrđuju mišljenje da su u nekadašnjem carevu stanu boravile osobe višega društvenog ranga, ali odgovor na pitanje tko su bili ti stanovnici ne može ići dalje od puke pretpostavke. Budući da je Palača bila carski posjed, vjerojatnim se čini da je postala administrativnim sjedištem carskih nadzornika ili upravitelja. U najmanju ruku, ondje su morali boraviti barem voditelj gineceja (Procurator gynaecii Iovensis, Dalmatiae Aspalatho) i njegovi administrativni pomoćnici, a daljnja nagađanja ne čine mi se osobito plodotvorna. Uz svakojake nadzornike, ne bi trebalo zanemariti i potrebu vojnog osiguranja objekta, s obzirom na prirodu proizvodnje i profil radne snage u gineceju. Ta zadaća zacijelo nije bila povjerena regularnim carskim trupama, već lokalnim oružanicima. Pretpostavka da su pojedini članovi carskih obitelji povremeno boravili u Palači ${ }^{113}$ ne čini se osobito uvjerljivom jer su moćnici u pravilu uvijek radije preferirali blizinu političkih, društvenih ili trgovačkih središta, u čemu se ni Salona ni Palača nisu mogli mjeriti s Konstantinopolom, Rimom, Tesalonikom ili Aleksandrijom. Osim toga, kako je već naglašeno, carskih je posjeda bilo diljem Carstva, pa nije jasno zbog čega bi baš u Dioklecijanovoj palači, gdje je djelovao i ginecej, povremeno boravili članovi carskih obitelji. Takav bi dolazak u svakom slučaju izazvao velike poremećaje u svakodnevnici, s obzirom na visok rang tako uglednih osoba. Njima bi trebalo osigurati ne samo smještaj, već i brojne druge pogodnosti, znamo li da je s članovima carske obitelji putovala i brojna osobna posluga i jaka vojna pratnja. Za takav smještaj u Palači, u kojoj je boravio znatan broj stanovnika, što potvrđuju i brojni keramički nalazi, naprosto nije bilo mjesta. ${ }^{114}$

Iako ni jedan literarni izvor ne daje povoda o boravku u Palači ikojeg od članova carskih obitelji tijekom 4. i 5. stoljeća, u hrvatskoj je historiografiji prihvaćeno mišljenje da se u njoj kratko vrijeme tijekom zime 424. - 425. zadržala sestra cara Honorija, Gala Placidija, s malim sinom Flavijem Placidom, kasnijim carem Valentinijanom III. ${ }^{115}$ Događaj je vezan uz previranja na zapadnom prijestolju, povezanih s uzurpacijom carske vlasti, koju je u Italiji proveo primicerij Ivan. ${ }^{116}$ Tu tvrdnju još od Bulićeva vremena ${ }^{117}$ nisu propuštali navesti oni autori koji bi se dotaknuli povi-

$\overline{112}$ DVORŽAK-SCHRUNK 1989: 92.

113 Isto 1989: 93; JOVIĆ GAZIĆ 2011: 167.

114 BULIĆ I KARAMAN 1927: 182; DVORŽAK-SCHRUNK 1989: 94.

115 BELAMARIĆ 1998²a: 30; Isti 2004: 30; RAPANIĆ 2007: 113 i bilj. 177. Ukoliko je Gala Placidija s djecom doista boravila u Palači, to se moglo zbivati tek kraće vrijeme u proljeće 425., a ne tijekom zime.

116 POSAVEC 2007: 15 i bilj. 30.

117 BULIĆ I KARAMAN 1927: 181. 
jesti Palače od Dioklove smrti do dolaska prvih izbjeglih Salonitanaca početkom 7. stoljeća. No, 1962. Lj. Karaman pokušao je argumentirati kako su ti navodi netočni jer se temelje na pogrešnoj i pretjerano slobodnoj interpretaciji literarnih izvora. ${ }^{118}$ Iako izvori to doista ne bilježe, otvorena je mogućnost da je tijekom pohoda vojske s Istoka Palača nakratko možda i poslužila kao privremeno sklonište Gali Placidiji i njezinoj djeci.

Još se jedno istaknuto ime dalmatinske povijesti 5. stoljeća nastojalo dovesti u vezu s Palačom. Riječ je o vojnom upravitelju Dalmacije Marcelinu, koji se pobunio protiv cara Valentinijana III. i ostvario gotovo samostalnu upravu nad Dalmacijom ${ }^{119}$, što mu je tolerirao i istočni car Lav I., dodijelivši mu prestižnu čast patricija. Štoviše, u nastojanju da intervenira na Zapadu i sredi stanje u Italiji, car mu u nekoliko navrata dodjeljuje i zapovjedništvo nad jakim vojnim snagama. Većina je autora sklona mišljenju kako je Marcelin za svoje sjedište odabrao Dioklecijanovu palaču ${ }^{120}$, iako tome nema opravdana razloga. Kao namjesnik provincije, Marcelin je morao stolovati u namjesničkoj palači u Saloni i nije bilo niti potrebe niti zakonskog opravdanja, osim, naravno, uzurpacije prostora, da ulazi u carski posjed, što je Palača nedvojbeno i bila. ${ }^{121}$

Spomen u Tome Arhiđakona pružio je povoda da se u Palaču smjesti još jedna prilično opskurna osoba, zanimljiva jedino po tome što je obnašala carsku čast, a zatim i čast salonitanskog biskupa. ${ }^{122}$ Radi se o Gliceriju, koji je na carsku čast stupio s položaja comes domesticorum cara Anicija Olibrija, a uz podršku germanskog vojskovođe Gundobada. ${ }^{123}$ Nezadovoljni samovoljnim postavljanjem i svrgavanjem careva u Italiji, istočni carevi Lav I. i Zenon poslali su u Italiju upravitelja Dalmacije, Marcelinova nećaka Julija Nepota. Njegova je zadaća bila Glicerijevo svrgavanje i preuzimanje carske vlasti. Svrgnutoga Glicerija Nepot nije umorio, već ga je dao zarediti i poslao ga u Salonu kao biskupa, ali nema nikakvih potvrda, kao ni razloga da bi Glicerije kao biskup boravio u Palači, a ne u biskupskom dvoru u Saloni, crkvenom središtu provincije.

Julije Nepot jedina je povijesna osoba čiji je boravak u Palači izrijekom potvrđen vremenski bliskim literarnim izvorima. ${ }^{124}$ Nakon što ga je u Italiji vojska izvikala za cara, položaj augusta slanjem carskog purpura priznao mu je i istočni car Zenon, a time su pod njegovu vlast potpala i sva carska dobra na područjima

\footnotetext{
118 KARAMAN 1962: 5-7; DVORŽAK-SCHRUNK 1989: 95; RAPANIĆ 2007: 113, bilj. 177.

119 NIKOLANCI 1985: 5; JOVIĆ GAZIĆ 2011: 167-168. O Marcelinu opširnije: POSAVEC 2002; Isti 2007.

120 BULIĆ I KARAMAN 1927: 175; DVORŽAK-SCHRUNK 1989: 95; RAPANIĆ 2007: 114; JOVIĆ GAZIĆ 2011: 167-168.

121 POSAVEC 2007: 66-67.

122 Isti 2003.

123 Isti 2002; Isti 2007: 20-21.

124 Anon. Vales., pars posterior: 7, 36; Marc. Com., Chron., s. a. 480.
} 
koja su se u to vrijeme još nalazila pod rimskom kontrolom. Slijedom toga, Nepot je lege artis ostvario i kontrolu nad Palačom. No, njegova je vladavina u Italiji kratko trajala jer ga je već sljedeće godine iz Ravene protjerao vojni zapovjednik Orest, postavivši na carsku čast vlastitoga sina Romula. Car Zenon taj čin nikada nije prihvatio, već je nastavio podržavati Julija Nepota kao zakonitoga cara Zapada. Nepot se, kao što je poznato, povukao u Dioklecijanovu palaču, u kojoj je poživio do smrti 480., nastojeći od carske vlasti u Konstantinopolu nekako ishoditi svoj povratak u Italiju. U međuvremenu je s vlasti 476. zbačen i Romul Augustul, što je događaj koji se tradicionalno smatra propašću carske vlasti na Zapadu. Romulova je vladavina, međutim, bila uzurpacija, a zakoniti je car još uvijek živio u Palači, koja je tako stekla funkciju ne samo službene carske rezidencije, već i središta posljednjeg preostatka nekadašnjega Zapadnog Rimskog Carstva. ${ }^{125}$

Koliko god ta vladavina u općim povijesnim okolnostima imala malo značenje ${ }^{126}$, to je jedino razdoblje kad je Dioklecijanova palača doista i imala funkciju službene carske rezidencije. ${ }^{127}$ Nepotova je vladavina kratko trajala, a na njegov petogodišnji boravak u Palači ne osvrće se ni jedan od sačuvanih literarnih izvora. Što se u tim godinama u Palači zbivalo i je li tamošnji ginecej još djelovao, zbog šutnje povijesnih izvora nije moguće kazati. Moglo bi se pretpostaviti da je prestao biti potreban i da je sastavljen izvan pogona nakon što je u Salonu preseljen ginecej iz Basijane. Kako su funkcionirali i izgledali Nepotov dvor i dvorski ceremonijal, kakav je bio njegov comitatus, carska pratnja, dvorska straža te koliko je administrativnih službenika imao na raspolaganju, pitanja su na koja nije moguće ponuditi ikakav odgovor. Nedvojbeno je da Nepotova rezidencija nije mogla imati sjaj i raskoš one Dioklecijanove u Nikomediji, kao ni carske na Palatinu. To doba vrijeme je potpunog rasapa, a financijska sredstva kojima je Julije Nepot raspolagao ne mogu se mjeriti s Dioklecijanovim. Do njegova dolaska i Palača je, u odnosu na izvorni izgled, već morala pretrpjeti određene preinake. Osim toga, Nepot jest bio legitiman car, ali je ponajprije bio bjegunac, koji je u Palači, nesiguran u vlastiti položaj, pronašao privremeno utočište, nadajući se povratku u Italiju, do kojega nikad nije došlo. Malo je vjerojatno da je iz Ravene pobjegao s više od dvaju - triju brodova i tek nekoliko prisnih prijatelja i odanih suradnika. No, u Dalmaciji je morao uživati podršku lokalne aristokracije te raspolagati određenim prihodima i kakvim-takvim utjecajem jer bi se u protivnom teško održao. Vjerojatno je upravo stoga i ubijen u uroti dvojice svojih časnika,

125 O Nepotovoj vladavini opširnije usp. POSAVEC 2007.

126 GOLDSTEIN 1992: 14.

127 Continuatio Haun. Prosperi ordo prior, 311, s. a. 480. 
Vijatora i Ovide. Burno razdoblje, koje je u Dalmaciji uslijedilo nakon Nepotove smrti, izlazi izvan okvira ovoga priloga. ${ }^{128}$

\section{Bibliografija}

\section{Izvori}

Chronica Gallica 511: Chronica Gallica a. CCCCLII et DXI. 1891. Prir. Th. Mommsen, MGH, Auctores Antiquissimi, Chronica minora saec. IV. V. VI. VII. Vol. I. Berolini: 615-666.

Chronicon Eusebii ab Hieronymo retractatum. 1866. Prir. J. P. Migne, Patrologia latina. Tom. XXVII. Paris.

Consularia Constantinopolitana. 1891. Prir. Th. Mommsen, MGH, Auctores antiquissimi. Vol. IX. Berolini (pretisak 1961. Berlin).

Consularia Italica. Anonymi Valesiani pars posterior. 1891. Prir. Th. Mommsen, MGH, Auctores Antiquissimi. Vol. IX. Berolini (pretisak 1961. Berlin).

Consularia Italica. Continuatio Hauniensis Prosperi ordo posterior. 1891. Prir. Th. Mommsen, MGH, Auctores Antiquissimi. Vol. IX. Berolini (pretisak 1961. Berlin).

Consularia Italica. Continuatio Hauniensis Prosperi ordo prior. 1891. Prir. Th. Mommsen. MGH, Auctores Antiquissimi. Vol. IX. Berolini (pretisak 1961. Berlin).

Epitomae de Caesaribus. 2009². Prev. T. M. Banchich. Buffalo-New York.

Eutropius, Flavius. 1934. Breviarium ab urbe condita. Prir. Gerolamo Bottoni. Milano

Euzebije. 2004. Crkvena povijest. Prir. M. Mandac. Split.

Fest, Rufije. 2011. Breviarium rerum gestarum populi Romani - Kratak pregled povijesti rimskog naroda. Prir. H. Gračanin [Biblioteka Latina \& Graeca LXI]. Zagreb.

Hieronymus, Chronicon. 1984³. Prir. R. Helm, Eusebius Werke 7, Die Chronik des Hieronymus, Griechische christliche Schriftsteller 47. Berlin.

Historia Augusta. 1994. Prir. D. Nečas Hraste. Zagreb.

Hydatii episcopi descriptio consulum ex quo primum ordinati sunt, Consularia Constantinopolitana cum additamento Hydatii, AD A. CCCCLXVIII. 1892. Prir. Th. Mommsen, MGH, Auctores antiquissimi. Vol. IX. Berolini.

${ }_{128}$ Nažalost, ni razdoblje koje je u Dalmaciji uslijedilo nakon propasti carske vlasti na Zapadu nije se činilo dovoljno atraktivnim kako bi potaknulo veći znanstveni interes. Literarnih je izvora izrazito malo, a ni arheološki materijal nije atraktivan, niti sustavno vrednovan. Tek Prokopijeve vijesti o Justinijanovu ostrogotskom ratu i kratkotrajnim ratnim operacijama na dalmatinskom tlu pobudile su nešto veće zanimanje hrvatskih istraživača, ali ponajprije u sklopu sumarnih kratkih pregleda razdoblja koje je prethodilo zbivanjima usko vezanima uz nacionalnu povijest. Hrvatska historiografija jedva da je za to pedesetogodišnje razdoblje napravila nekakav odmak od rezultata koje je iznio još F. Šišić. Usp. ŠIŠIĆ 1925: 154-174; DVORŽAK-SCHRUNK 1989: 95-97; GOLDSTEIN 1992; POSAVEC 1996. Literaturu o navedenom razdoblju usp. u MATIJAŠIĆ 2012: 188-192. 
Konstantin Porfirogenet. 2003. De administrando imperio / O upravljanju carstvom. Prir. N. Tomašić, G. Moravcsik, R. J. H. Jenkins. Zagreb.

Ioannis Malalae Chronographia. 2000. Prir. Hans Thurn, Corpus fontium historiae Byzantinae 35. Berlin-New York.

Laktancije. 2005. O smrtima progonitelja. Prir. N. Cambi, B. Lučin. Split.

Marcellini viri clarissimi comitis Chronicon-Prejasni muž komes marcelin, Kronika. 2006. Prir. H. Gračanin, B. Kuntić-Makvić [Biblioteka Latina \& Graeca XXXVI]. Zagreb.

Notitia dignitatum occidentes. 1876. O. Seeck, Berolini.

Prosperi Tironis epitoma chronicon. 1892. Prir. Th. Mommsen, MGH, Auctores Antiquissimi, Chronica minora saec. IV. V. VI. VII. Vol. I. Berolini: 341-499.

Toma Arhiđakon. 2003. Historia Salonitana, Povijest salonitanskih i splitskih prvosvećenika. Prir. O. Perić, M. Matijević-Sokol, R. Katičić. Split.

\section{Literatura}

ADAM, Robert. 1764. Ruins of the Palace of the Emperor Diocletian at Spalato in Dalmatia. London: Printed for the Author (pretisak 1996. Split: Logos).

BABIĆ, Ivo. 2004. Egipatski utjecaji u Dioklecijanovoj palači. Vjesnik za arheologiju $i$ historiju dalmatinsku 96: 719-744.

BARNES, Timothy David. 1982. The New Empire of Diocletian and Constantine. Cambridge-London: Harvard University Press.

BARNES, Timothy David. 1996 ${ }^{5}$. Constantine and Eusebius. Cambridge-London: Harvard University Press.

BASIĆ, Ivan. 2010. Gradovi obalne Dalmacije u De administrando imperio: najstarija povijest Splita u svjetlu dvaju pojmova Konstantina VII Porfirogeneta. Radovi-Zavod za hrvatsku povijest 42: 65-82.

BASIĆ, Ivan. 2012. Spalatum - ager Salonitanus? Prilog tumačenju pravno-posjedovnoga položaja priobalja Splitskoga poluotoka u preddioklecijanskome razdoblju. Povijesni prilozi 42: 9-42.

BELAMARIĆ, Joško. 1998. The first centuries of christianity in Diocletian's palace in Split. U Radovi XIII. međunarodnog kongresa za starokršćansku arheologiju, ur. Nenad Cambi, Emilio Marin, 55-68. Vol. III. Split: Arheološki muzej u Splitu.

BELAMARIĆ, Joško. $1998^{2}$ a. Split-od carske palače do grada. Split: Grad Split.

BELAMARIĆ, Joško. 2003. The date of foundation and original function of Diocletian's palace at Split. Hortus artium medievalium 9: 173-185.

BELAMARIĆ, Joško. 2004. Gynaeceum Iovense Dalmatiae-Aspalatho. U DIOKLETIAN UND DIE TETRARCHIE 2004: 141-162. Isti rad na hrvatskome jeziku: Prilozi povijesti umjetnosti u Dalmaciji 40: 5-42.

BOŠKOVIĆ, Ivan. 2008. Svi hrvatski Dioklecijani. Croatica et Slavica Iadertina IV: 401-435.

BULIĆ, Frane, Ljubo KARAMAN. 1927. Palača cara Dioklecijana u Splitu. Zagreb: Redovno izdanje Matice hrvatske (pretisak 2006. Split: Ex libris). 
BULIĆ, Frane. 2005. Car Dioklecijan. Njegovo ime, njegova domovina i mjesto, gdje se rodio; kada, gdje i kako je umro. U Dioklecijan i Split, ur. Frane Bulić, Nenad Cambi, Ivo Babić, 145-180. Split: Slobodna Dalmacija. (pretisak 1915-1919. Vjesnik Hrvatskog arheološkog društva, n. s. XIV: 99-171).

BUŽANČIĆ, Radoslav. 2011. Dioklecijanova palača, kastron Aspalathos i njegov palatium sacrum. Klesarstvo i graditeljstvo 1-2: 5-39.

CAMBI, Nenad. 1977. Two Heads of Tetrarchic Period from Diocletian's Palace at Split. Archaeologia Jugoslavica 17: 23-28.

CAMBI, Nenad. 1981. Križ na zapadnim vratima Dioklecijanove palače. Kulturna baština 11-12: 6-14.

CAMBI, Nenad. 1991. Antički portret u Hrvatskoj. Zagreb: Nakladni zavod Matice Hrvatske.

CAMBI, Nenad. 1994. Dioklecijanova palača i Dioklecijan, lik i ličnost. U DIOKLECIJANOVA PALAČA 1994: 11-27.

CAMBI, Nenad. 1997. Diocletian (the Person and the Personality) and his Palace. Zagreb-Split (prijevod teksta Dioklecijanova palača i Dioklecijan, lik i ličnost. U DIOKLECIJANOVA PALAČA 1994: 11-27).

CAMBI, Nenad. 1998. Pristup razmatranju skulpturalnog programa Dioklecijanove palače u Splitu. Kulturna baština 19: 12-22.

CAMBI, Nenad. 1999. Kontinuitet ili diskontinuitet: Kasna antika - rani srednji vijek. Historijski zbornik LII: 107-116.

CAMBI, Nenad. 2000. IMAGO ANIMI, Antički portret u Hrvatskoj. Split: Književni krug.

CAMBI, Nenad. 2002a. Antika. Zagreb: Naklada Ljevak.

CAMBI, Nenad. 2002b. Kiparstvo. U LONGAE SALONAE 2002: 115-162.

CAMBI, Nenad. 2003. Toma Arhiđakon, Dioklecijan i tetrarsi. Starohrvatska prosvjeta III/30: 103-111.

CAMBI, Nenad. 2004. Tetrarchic Practice in Name Giving. U DIOKLETIAN UND DIE TETRARCHIE 2004: 38-46.

CAMBI, Nenad. 2005a. Dioklecijanova palača i Dioklecijan, Lik i ličnost. U Dioklecijan i Split, ur. Frane Bulić, Nenad Cambi, Ivo Babić, 145-180. Split: Slobodna Dalmacija.

CAMBI, Nenad. 2005b. Kiparstvo rimske Dalmacije. Split: Književni krug

CAMBI, Nenad. 2010. Dioklecijan u Splitu. Radovi - Zavod za hrvatsku povijest 42: 169-194.

CAMBI, Nenad. 2013. Bilješke o tetrarhijskoj religijskoj politici. U Znakovi i riječi Signa et litterae, ur. Bruna Kuntić-Makvić, Inga Vilogorac Brčić, 133-154. Vol. IV. Zagreb: Sveučilište u Zagrebu, Filozofski fakultet, Odsjek za povijest, FF press.

CAMBI, Nenad. 2014. Dioklecijanova palača. Katalog izložbe Klasični Rim na tlu Hrvatske: arhitektura, urbanizam, skulptura, ur. Marina Šegvić, Danijela Marković, 125-131. Zagreb: Galerija Klovićevi dvori.

CAMBI, Nenad, Joško BELAMARIĆ, Tomislav MARASOVIĆ (ur.). 2009. Dioklecijan, tetrarhija i Dioklecijanova palača o 1700. obljetnici postojanja - Zbornik 
radova / Diocletian, Tetrarchy and Diocletian's palace on the 1700th Anniversary of Existence-Proceedings [Biblioteka knjiga Mediterana 54]. Split: Književni krug.

DEMANDT, Alexander. 2007². Die Spätantike. Römische Geschichte von Diokletian bis Justinijan 284.-565. n. Chr. München: Beck.

DEMICHELI, Dino. 2009. Novi antički natpisi iz „podruma“ Dioklecijanove palače. Opuscula archaeologica 32 [2008]: 55-79.

DIOKLECIJANOVA PALAČA 1994. Dioklecijanova palača, katalog izložbe / Exhibition Catalogue, ur. Nenad Cambi, Tomislav Marasović. Split: Lions club.

DIOKLETIAN UND DIE TETRARCHIE 2004. Diokletian und die Tetrarchie. Aspekte einer Zeitenwende, ur. A. Demandt, A. Goltz, H. Schlange-Scheningen. Berlin-New York: W. de Gruyter.

DVORŽAK-SCHRUNK, Ivančica. 1989. Dioklecijanova palača od 4. do 7. stoljeća u svjetlu keramičkih nalaza. Vjesnik Arheološkog muzeja u Zagrebu 22: 91-105.

DVORŽAK-SCHRUNK, Ivančica, Vlasta BEGOVIĆ. 2012. Diocletian's palace and Split: transfering ideas from a maritime villa to a Christian city. Vjesnik Arheološkog muzeja u Zagrebu III/XLV: 507-515.

DYGGVE, Eynar. 1965. O izvornom izgledu antičkog Peristila. Urbs 4 [1961-1962]: 55-60.

DYGGVE, Eynar. 1996. Povijest salonitanskog kršćanstva. Split: Književni krug.

FISKOVIĆ, Cvijeto. 2005. Dioklecijanova palača. Prilog proučavanju i zaštiti, SplitZagreb: Ex libris.

GABRIČEVIĆ, Branko. 1987. Peristil Dioklecijanove palače u Splitu kao kultni prostor. U ISTI, Studije i članci o religijama i kultovima antičkog svijeta. Split: Književni krug.

GAMZIGRAD 1983. Gamzigrad-kasnoantički carski dvorac. Katalog izložbe, ur. Stojan Ćelić. Zaječar: Galerija SANU, Narodni muzej u Zaječaru.

GOLDSTEIN, Ivo. 1992. Bizant na Jadranu: Bizant na Jadranu od Justinijana do Bazilija I. Zagreb: Latina \& Graeca.

ILAKOVAC, Boris. 1982. Rimski akvedukti na području sjeverne Dalmacije. Zagreb: Sveučilišna naklada Liber.

JELIČIĆ-RADONIĆ, Jasna. 2008. Avrelia Prisca. Prilozi povijesti umjetnosti u Dalmaciji 41/1: 5-25.

JELIČIĆ-RADONIĆ, Jasna. 2011. Hram Dioklecijanova doba kod Porta Andetria u Saloni. Prilozi povijesti umjetnosti u Dalmaciji 42/1: 5-28.

JOVIĆ GAZIĆ, Vedrana. 2011. Razvoj grada od kasne antike prema srednjem vijeku: Dubrovnik, Split, Trogir, Zadar - stanje istraženosti. Archaeologia Adriatica V: 151-196.

KARAMAN, Ljubo. 1940a. O počecima srednjovjekovnog Splita do godine 800. Hoffillerov zbornik: načni radovi posvećeni Viktoru Hoffilleru o 60 godišnjici njegova života, 19. veljače 1937. godine, 419-436. Zagreb: Hrvatsko arheološko društvo.

KARAMAN, Ljubo. 1940b. Događaji iz petog stoljeća u Dioklecijanovoj palači. Prilozi povijesti umjetnosti u Dalmaciji 14: 5-10.

KÄHLER, Heinz. 1965. Split i Piazza Armerina, Rezidencije dvaju tetrarha. Urbs 4 [1961-1962]: 97-109. 
KOLB, Frank. 1987. Diokletian und die Erste Tetrarchie. Improvisation oder Experiment in der Organisation monarchischer Herrschaft? . Berlin, New York: Walter de Gruyter.

KUHOFF, Wolfgang. 2001. Diokletian und die Epoche der Tetrarchie. Das Romische Reich zwischen Kriesenbewältigung und Neuaufbau (284-313 n. Chr.). Frankfurt am Main: Peter Lang.

LONGAE SALONAE. 2002. Ur. Emilio Marin. Split: Arheološki muzej u Splitu.

MADIRACA, Vinko. 2011. Sondažna arheološka istraživanja na prostoru crkve Sv. Roka i Peristila Dioklecijanove palače u Splitu. Kulturna baština 37: 127-142.

MARASOVIĆ, Duško. 2009. Povijesna jezgra Splita, Studije - programi - realizacije. Obnova povijesne jezgre Splita 5. Split: Grad Split, Gradsko poglavarstvo, Služba za staru gradsku jezgru.

MARASOVIĆ, Jerko. 1997. Obnova povijesne jezgre Splita 2. Split: Grad Split, Gradsko poglavarstvo, Služba za staru gradsku jezgru.

MARASOVIĆ, Jerko, Tomislav MARASOVIĆ. 1968. Dioklecijanova palača. Zagreb: Zora.

MARASOVIĆ, Jerko, Tomislav MARASOVIĆ, Snježana PEROJEVIĆ. 2005. Kultne građevine Dioklecijanove palače u Splitu. Histria antiqua 13: 427-436.

MARASOVIĆ, Katja, Daniela MATETIĆ POLJAK. 2010. Upotreba dekorativnog kamena u Dioklecijanovoj palači u Splitu. Histria antiqua 19: 89-100.

MARASOVIĆ, Tomislav. 1994. Dioklecijanova palača - svjetska kulturna baština. Zagreb-Split: Naklada Dominović, Naklada Buvina.

MARASOVIĆ, Tomislav. 1995a. Dioklecijanova palača - svjetska kulturna baština. Zagreb-Split: Naklada Dominović, Naklada Buvina.

MARASOVIĆ, Tomislav. 1995b. O hramovima Dioklecijanove palače. Prilozi povijesti umjetnosti u Dalmaciji 35, Petriciolijev zbornik I: 89-103.

MARASOVIĆ, Tomislav. 2011. „Kibelin hram“ Dioklecijanove palače i njegova ranosrednjovjekovna uporaba. Kačić 41-43 [2009-2011]: 689-698.

MARASOVIĆ, Tomislav, Tomislav ALUJEVIĆ. 2007. Dioklecijanov stan u splitskoj palači. Prostor 2 [34]/15 [2007]: 154-179.

MARIN, Emilio. 1988. Starokršćanska Salona. Zagreb: Latina \& Graeca.

MARINKOVIĆ, Vinka. 2010. Pregled arheoloških istraživanja i restauratorsko-konzervatorskih zahvata u Dioklecijanovoj palači u Splitu. Kulturna baština 36: 239-278.

MARINKOVIĆ, Vinka. 2014. Nekoliko novih figuralnih prikaza u Dioklecijanovoj palači. Vjesnik za arheologiju i historiju dalmatinsku 107: 291-308.

MATIJAŠIĆ, Robert. 2012. Povijest hrvatskih zemalja u kasnoj antici od Dioklecijana do Justinijana. Zagreb: Leykam international.

MATULIĆ, Branko. 2005. Mozaički nalazi u perimetru Dioklecijanove palače. Kulturna baština 32: 227-246.

McNALLY, Sheila, 1996. The Architectural Decoration of Diocletian's Palace: Ornament in Context [BAR International Series 639]. Oxford: Archaeopress.

MILOTIĆ, Ivan. 2013. Milanski edikt, prijevod, komentar i studija. Zagreb: Kršćanska sadašnjost. 
NIEMANN, Georg. 1910. Der Palast Diokletians in Spalato. Wien: Hölder [pretisak 2005. Dioklecijanova palača u Splitu, prev. M. Marasović. Split: Književni krug Split].

NIKOLANCI, Mladen. 1985. „Dalmatinska dinastija“ i propast Zapadnog Rimskog Carstva. Radovi Instituta za hrvatsku povijest 18: 5-22.

NIKŠIĆ, Goran. 2004. The Restoration of Diocletian's Palace-Mausoleum, Temple, and Porta Aurea (with the analysis of the original architectural design). U DIOKLETIAN UND DIE TETRARCHIE 2004: 163-171.

NIKŠIĆ, Goran. 2009. Dioklecijanova palača - od projekta do izvedbe. U Cambi, Belamarić i Marasović 2009: 117-133.

NIKŠIĆ, Goran. 2012. Dioklecijanova palača - reinterpretacija izvorne namjene i arhitekture, Niš i Vizantija X: 219-236.

NOVAK, Grga. 2003. Povijest Splita. Split: Slobodna Dalmacija (pretisak).

PEROJEVIĆ, Snježana, Katja MARASOVIĆ, Jerko, MARASOVIĆ. 2009. Istraživanja Dioklecijanove palače od 1985. do 2005. godine. U CAMBI, BELAMARIĆ I MARASOVIĆ 2009: 51-94.

POPOVIĆ, V. Aleksandar. 2010. Imperator Galerije i Felix Romuliana u svetlu pisanih izvora. Niš i Vizantija VIII: 479-489.

POSAVEC, Vladimir. 1996. Prilog poznavanju ostrogotskog razdoblja u Dalmaciji. $\mathrm{Hi}$ storijski zbornik XLIX: 1-15.

POSAVEC, Vladimir. 1997. Pogled na prošlost rimske Dalmacije u prvoj polovici V. stoljeća. Historijski zbornik L: 9-20.

POSAVEC, Vladimir. 2002. Patricij Marcelin - kršćanin ili poganin. Latina \& Graeca XXI [2002]/2: 59-64.

POSAVEC, Vladimir. 2003. Glicerije - zapadnorimski car i salonitanski biskup. Latina \& Graeca XXII [2003]/4: 48-52.

POSAVEC, Vladimir. 2007. Dalmacija $u$ vrijeme Marcelina i Julija Nepota. Split: Književni krug.

POTTER, S. David. 2004. The Roman Empire at Bay: AD 180-395. London-New York: Routledge.

RAPANIĆ, Željko. 2007. Od carske palače do srednjovjekovne općine. Split: Književni krug.

REES, Roger. 2004. Diocletian and the Tetrarchy. Edinburgh: Edinburgh University Press.

RENDIĆ MIOČEVIĆ, Duje. 1992. O uništenom središnjem motivu friza Dioklecijanova mauzoleja. Prilozi povijesti umjetnosti u Dalmaciji 32, Prijateljev zbornik I: 99-115.

RISMONDO Tajma. 2005. Unutrašnja dekoracija istočnih termi Dioklecijanove palače u Splitu/Arheološka istraživanja 2002. godine. Vjesnik za arheologiju i povijest dalmatinsku 98: 151-158.

SALONA CHRISTIANA. 1994. Ur. Emilio Marin. Split: Arheološki muzej u Splitu.

SCARRE, Chris. 1995. Chronicle of the Roman Emperors. London-New York: Thames \& Hudson.

SELEM, Petar. 2008. Lica bogova. Izidin trag. Zagreb: Matica hrvatska. 
SUIĆ, Mate. 2003. Antički grad na istočnom Jadranu. II. izmijenjeno i dopunjeno izdanje. Zagreb: Golden marketing.

ŠIŠIĆ, Ferdo. 1925. Povijest Hrvata u doba narodnih vladara. Zagreb: Matica hrvatska. ŠUŠNJAR, Bogdan. 2003. Vila cara Dioklecijana u Splitu. Split: Logos.

TADINAC, Ivana. 2011. Sfinge iz Dioklecijanove palače. Kulturna baština 37: 371-400.

TADINAC ŠEĆER, Ivana. 2014. Novi nalazi fragmenata s uklesanim tipičnim ranokršćanskim križevima u Splitu. Crkva u svijetu 48/3 [2013]: 380-403.

TOMOVIĆ, Miodrag. 2009. Šarkamen (Eastern Serbia), an Imperial Tetrarchic Palace, Mausoleum and Memorial Complex. U Cambi, Belamarić i Marasović 2009: 411-470. VLAŠIĆ JURIĆ, Vesna. 2011. Dioklecijanova palača na prikazima u Grafičkoj zbirci

Nacionalne i sveučilišne knjižnice u Zagrebu. Kroatologija 2/1: 205-216.

WILLIAMS, Stephen. 1997. Diocletian and the Roman Recovery. New York: Routledge. WILKES, Joseph John. 1993. Diocletian's Palace, Split: a Residence of a Retired Roman Emperor. Sheffield: Blackwell.

\section{Was Diocletian's Palace Ever Used as an Imperial Residence?}

Diocletian's Palace is rarely mentioned in ancient literary sources but it does not make it stand out among other imperial residences. The first descriptions of its size, shape or architectonic appearance came up in the work of Constantine VII Porphyrogenitus and Thomas Archdeacon, but the function of the Palace had completely changed. Findings based on more recent research point out to the necessity of re-examination of a part of prior interpretations of Diocletian's Palace. In the paper the accent is put on the question what its actual purpose was from the moment it had been built to the collapse of imperial government in the western part of the Empire and whether it had ever had the function of an actual imperial residence. The Croatian science has developed a thesis that the building represented a well-fortified residence of the sovereign who had abdicated from the throne but in a way continued to participate in the governing, and the Palace was supposed to have served as a permanent monument to the tetrarchy and its founder. As there are no strong arguments in favour thereof, all reflections from the field of symbolism and iconography cannot be anything but an unfounded assumption. Even the illogical details in the fortification system remain unexplained. The Palace is by its position, which is lower than the surrounding ground, completely inappropriate for the defence, and the walls on all three terrestrial sides have arch openings that are too wide and made too low. Great arch openings are found above all terrestrial gates, being the weakest points in the defence. On the other hand, the imperial quarters are relatively small in comparison to the remainder of the structure. The residential part takes up but a quarter of the space within the walls 
and they too, apart from the cryptoporticus, whose purpose is just a communication between the rooms of the quarters, have no other communication towards their surroundings apart from the gates. The residential part is architectonically closed towards the inner part of the structure as well. There were attempts to explain numerous illogical details in the construction on the account of the speed of the construction work, incompleteness or the architects' mistakes which were solved by the builders on the go. However, recent achievements in the field and knowledge gained during the intensive recovery work on the Palace point out to the need of a thorough reinterpretation of the building's original purpose. As the only safe general spot, verified by literary sources as well, the fact remains that the emperor, having abdicated, withdrew to the Palace where he intended to spend the last years of his life. Diocletian's Palace was by all means the residence of a noble and powerful figure, but it is difficult not to agree with the statement that in Diocletian's lifetime it couldn't have had an official, but an exclusively private character. As an intricate part of a great reforming programme, Diocletian's abdication was an elaborate and intentional move. A publically exhibited act clearly and undoubtedly represented an abdication from power with a simultaneous surrender of all imperial authorities to successors determined in advance and publically presented. Accordingly, such an act assumed a complete renouncing of power in every aspect and on every level. The question about the means for sustenance and everyday needs of the former emperor has been completely ignored. There is no mention or insinuation in literary sources that older augustus enjoyed a certain yearly apanage from the state treasury. In the ager of Salona there could have been certain Diocle's land properties, but the retired emperor must have had a certain permanent source of income. As far as I know, the question has not been posed in scientific literature up until recently, but it is easily solved through a wellfounded opinion of J. Belamarić on a gynaeceum in the Palace. This would mean that the former emperor had decided to become an entrepreneur and not farmer in his old age. The thesis by Belamarić has recently been empowered by G. Nikšić as well with new and convincing arguments. The gynaeceum in the Palace is confirmed by a statement in Notitia Dignitatum with a typical attribute Iovensis which can be connected exclusively to Diocletian's appellative Iovius. A possible later setting of the gynaeceum into the Palace, in the period following Dioclo's death, is opposed by the simultaneous construction of the aqueduct delivering water to the Palace and its very construction, as well as the capacity of Diocletian's aqueduct far outranging the one delivering water to neighbouring Salona. The sewage system found in its northern part allows the presumption that approximately the same amount of water coming through aqueduct also entered inside the city walls. No clear archaeological proof was found for the above mentioned gynaeceum, but the northern part of the palace is nevertheless the least preserved. However, no archae- 
ological proof was found inside the walls for the tetrarchic cult, while the gynaeceum was directly confirmed by a literary source, which is an official document. Being a pragmatic, Diocletian most probably carefully reconsidered life after the planned abdication. Also, general circumstances while he was still in power worked in his favour. By the introduction of tetrarchy, Roman army enormously grew in size, and this enlarged number of soldiers needed not only to be paid, but also to be supplied with panoply and combat suits. In my opinion, that's where Diocletian saw an opportunity to design the Palace as a fortified workhouse, gynaeceum, in which its owner had also a luxuriously furnished home. In this context, it is also possible to compare it to Galerius' fortified palace in Gamzigrad. We can only speculate whether Diocletian intended to start the production even before the abdication, which could be one of the reasons for building in haste, or abdication occurred earlier than planned due to illness. The beginning of the production is not known, but it must have occurred only after the withdrawal from power. After Diocles' death the Palace became imperial property. Diocles died without legal heirs, but even if this had not been the case, the gynaeceum inside the walls, which was the only one in Dalmatia at the time, would surely have been expropriated in the name of the imperial treasury, and this might even have happened in the last years of its owner's life. At the same time, the first changes occurred in the palace caused partly by the change of the official attitude towards Christianity after the Edict of Galerius, and partly due to the probable need for conversion in former Diocles' private lodgings. The archaeological confirmation of early architectural interventions can be seen in western thermae. There are firm indications that they were not a part of the original builder's construction of the Palace and they could have been a consequence of alterations brought by a redistribution of the new residents' needs in the former emperor's quarters. The life in the Palace through the $4^{\text {th }}$ century having been fairly dynamic is confirmed by numerous findings of pottery, lamps, glass and coins, and they confirm the opinion that higher social ranking persons resided in the onetime quarters of the former emperor. It was the place where the head of the gynaeceum and his administrative assistants had to reside. There have been aspirations to bring one more prominent name of Dalmatian history in the $5^{\text {th }}$ century into connection with the Palace. That was Marcelinus, the military commander of Dalmatia, who obtained an almost independent command of the province, which was tolerated even by the eastern emperor Leo I. As the imperial governor of the province, Marcelinus had to reside in the governor's palace in Salona and there was no legal justification to enter the imperial property, which Diocletian's Palace undoubtedly was. Julius Nepos is the only historical figure whose residence in the Palace has been literally confirmed by contemporary literary sources. After eastern emperor Zeno had also recognised his rank of augustus by sending him the imperial purple, every imperial property in the territories still 
under Roman control at the time fell under his rule. As it followed, Nepos gained control over the Palace as well. However, he was banished from Ravenna as soon as the next year by military commander Orestes, who bestowed the imperial honour on his own son Romulus. Emperor Zeno continued to support Julius Nepos as the legitimate emperor of the West, and he retired to Diocletian's Palace where he lived until his death in 480 A. D. Diocletian's Palace thus assumed the function of not solely an official imperial residence, but the centre of the last remnant of the Western Empire as well. As small as the significance of this reign in general historical circumstances was, it was the only period when Diocletian's Palace really obtained the function of the official imperial residence.

Keywords: Diocletian, tetrarchy, Split, Roman Empire, late antiquity, gynaeceum, palace, residence, villa

Ključne riječi: Dioklecijan, tetrarhija, Split, Rimsko Carstvo, kasna antika, ginecej, palača, rezidencija, vila

Vladimir Posavec

Privatna klasična gimnazija

Harambašićeva 19

HR-10000 Zagreb

vposavec.vp@gmail.com 


\section{FILOZOFSKI FAKULTET SVEUČILIŠTA U ZAGREBU \\ ZAVOD ZA HRVATSKU POVIJEST \\ INSTITUTE OF CROATIAN HISTORY \\ INSTITUT FÜR KROATISCHE GESCHICHTE}
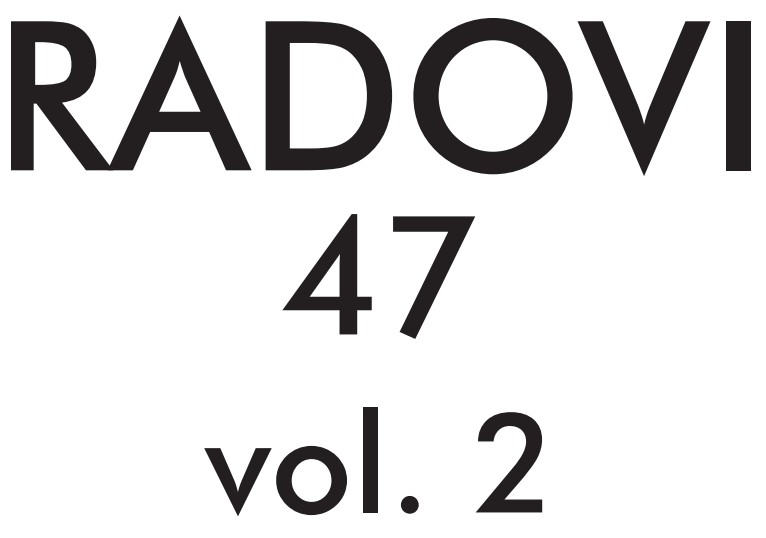

ZAVOD ZA HRVATSKU POVIJEST

FILOZOFSKOGA FAKULTETA SVEUČILIŠTA U ZAGREBU

FF press

ZAGREB 2015. 


\title{
RADOVI ZAVODA ZA HRVATSKU POVIJEST FILOZOFSKOGA FAKULTETA SVEUČILIŠTA U ZAGREBU
}

\author{
Knjiga 47, vol. 2
}

\author{
Izdavač / Publisher \\ Zavod za hrvatsku povijest \\ Filozofskoga fakulteta Sveučilišta u Zagrebu \\ FF-press \\ Za izdavača / For Publisher \\ Vlatko Previšić \\ Glavni urednik / Editor-in-Chief \\ Hrvoje Gračanin \\ Izvršna urednica / Executive Editor \\ Inga Vilogorac Brčić \\ Uredništvo / Editorial Board
}

Bruna Kuntić-Makvić (stara povijest/ancient history), Zrinka Nikolić Jakus (srednji vijek/ medieval history), Hrvoje Petrić (rani novi vijek/early modern history), Željko Holjevac (moderna povijest/modern history), Tvrtko Jakovina (suvremena povijest/contemporary history),

Silvija Pisk (mikrohistorija i zavičajna povijest/microhistory and local history),

Zrinka Blažević (teorija i metodologija povijesti/theory and methodology of history)

Međunarodno uredničko vijeće / International Editorial Council

Denis Alimov (Sankt Peterburg), Živko Andrijašević (Nikšić), Csaba Békés (Budapest), Rajko Bratož (Ljubljana), Snježana Buzov (Columbus, Ohio), Svetlozar Eldarov (Sofija), Toni Filiposki (Skopje), Aleksandar Fotić (Beograd), Vladan Gavrilović (Novi Sad), Alojz Ivanišević (Wien),

Egidio Ivetić (Padova), Husnija Kamberović (Sarajevo), Karl Kaser (Graz),

Irina Ognyanova (Sofija), Géza Pálffy (Budapest), Ioan-Aurel Pop (Cluj),

Nade Proeva (Skopje), Alexios Savvides (Kalamata), Vlada Stanković (Beograd), Ludwig Steindorff (Kiel), Peter Štih (Ljubljana)

Izvršna urednica za tuzemnu i inozemnu razmjenu / Executive Editor for Publications Exchange Kristina Milković

Tajnik uredništva / Editorial Board Assistant
Dejan Zadro

Adresa uredništva/Editorial Board address

Zavod za hrvatsku povijest, Filozofski fakultet Zagreb, Ivana Lučića 3, HR-10 000, Zagreb

Tel. ++385 (0)1 6120 150, 6120 158, faks ++385 (0)1 6156879

Časopis izlazi jedanput godišnje / The Journal is published once a year

Časopis je u digitalnom obliku dostupan na / The Journal in digital form is accessible at Portal znanstvenih časopisa Republike Hrvatske „Hrčak“ http://hrcak.srce.hr/radovi-zhp

Financijska potpora za tisak časopisa / The Journal is published with the support by

Ministarstvo znanosti, obrazovanja i športa Republike Hrvatske

Časopis je indeksiran u sljedećim bazama / The Journal is indexed in the following databases:

Directory of Open Access Journals, EBSCO, SCOPUS, ERIH PLUS 
Naslovna stranica

Iva Mandić

Grafičko oblikovanje i računalni slog

Marko Maraković

Lektura

Samanta Paronić

Tisak

Web2tisak, Zagreb

Naklada

250 primjeraka

Časopis je u digitalnom obliku dostupan na Portalu znanstvenih časopisa Republike Hrvatske ,Hrčak“ http://hrcak.srce.hr/radovi-zhp

The Journal is accessible in digital form at the Hrcak - Portal of scientific journals of Croatia http://hrcak.srce.hr/radovi-zhp 


\section{RADOVI 47}

\section{vol. 2}



